5.

\title{
El universo
}

chibcha

según varios

pensadores

y la visión de Luis

Alberto Acuña

como historiador

y artista

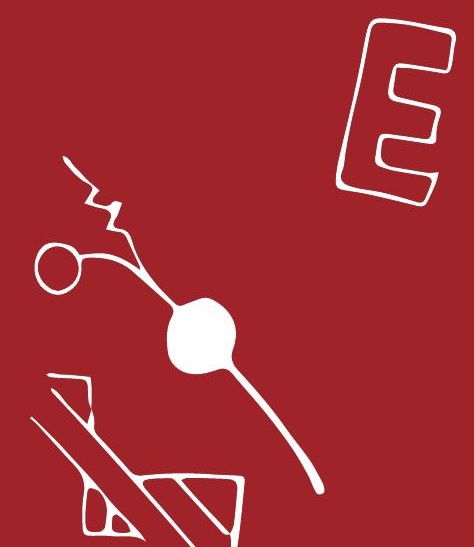




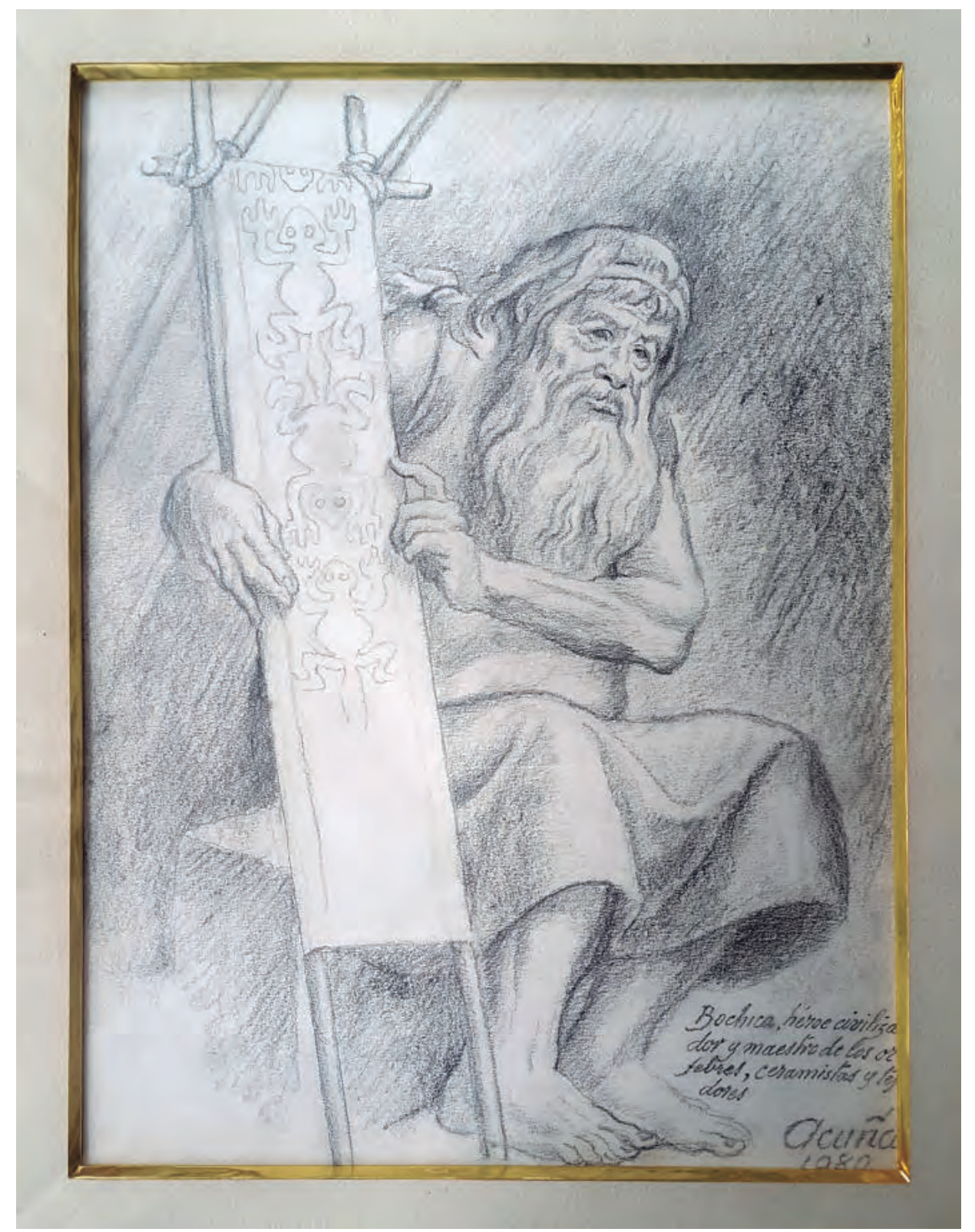

Bochica, héroe civilizador y maestro de los orfebres, ceramistas y tejedores. Carboncillo sobre papel. Luis Alberto Acuña. (1980) Fuente: Colección privada. Fotografía: Diego Carrizosa. 


\section{Los orígenes y la}

\section{estructura de la}

cultura chibcha

antes de la

Conquista

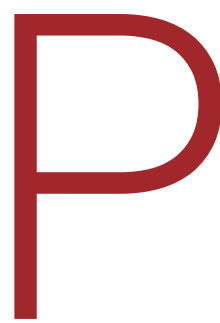

ara ampliar sus conocimientos sobre la naturaleza de la cultura chibcha y concebir las bases de su proceso de indagación teórica y plástica sobre la representación del arte y del imaginario que comprende el universo cosmogónico de este grupo humano, Acuña consultó, entre otras fuentes, los escritos de los autores José de Acosta S. J., Miguel Triana, Vicente Restrepo, Konrad Theodor Preuss, Paul Radin, fray Pedro Simón, Guillermo Valencia y Liborio Zerda, entre otros.

Según se colige de la bibliografía presentada en El arte de los indios colombianos (Ensayo crítico e histórico), Acuña (1935), el artista santandereano consultó La civilización chibcha (Triana 1922), donde se menciona que, antes de la Conquista, los chibchas gozaban de un reposado estado de civilización que se reflejaba en aspectos morales, intelectuales y artísticos y que los chibchas poseían una cosmogonía que explicaba el origen de su universo, por medio de la cual fortalecían sus sentimientos sobre lo místico. De lo anterior es posible deducir que la cultura chibcha tenía una amplia riqueza simbólica que expresaba mediante sus signos culturales. 
Acuña también estuvo al tanto del pensamiento consignado por el químico y geólogo antioqueño Vicente Restrepo en su libro Los chibchas antes de la conquista española ([1895] 1972). El antioqueño señaló que los dos textos históricos primordiales que sirvieron de base conceptual para que los cronistas conocieran de antemano las costumbres de los chibchas fueron redactados por los conquistadores Gonzalo Jiménez de Quesada, fundador del Nuevo Reino de Granada, y Juan de Castellanos, quien se ordenó en el Nuevo Mundo.

Castellanos sirvió a la ciudad de Tunja como sacerdote desde 1562, hasta su muerte acaecida en 1607, tiempo en el cual estudió de primera mano la cultura chibcha; su libro Historia del Nuevo Reino de Granada, publicado en Madrid en 1886 por parte de la imprenta de A. Pérez Dubrull, se convirtió entonces en un documento básico de toda disertación que se relacione con este pueblo. (Restrepo [1895] 1972)

Además de los dos autores mencionados, Acuña también citó en sus escritos las Noticias historiales de las conquistas de Tierra Firme en las Indias Occidentales ([1626] 1953), de fray Pedro Simón, sacerdote de la comunidad franciscana que llegó a Santafé en 1604. Simón recopiló gran cantidad de escritos sobre la cultura chibcha, y se dedicó a realizar observaciones sobre sus tradiciones, leyendas y mitos y así se convirtió en el escritor que más compiló información acerca de esta cultura, razón por la cual sus textos son considerados obligatorios para el estudio de los procesos de descubrimiento y conquista de lo que hoy es nuestro territorio.

Por su parte, Restrepo ([1895] 1972) anotó que los españoles llamaron chibchas a sus habitantes por escucharlos utilizar habitualmente este término, que significa persona; y moscas en razón de que eran tan profusos como estas. Por otra parte, hace una referencia a fray Pedro Simón ([1626] 1953), quien puntualizó que la región de Bacatá, al igual que el lenguaje que allí se hablaba, se denominaba chibcha.

Autores como Triana (1922, [1924] 1970), Acuña (1935, 1942a, 1942b), Zerda (1947), Hernández (1949), Jiménez de Muñoz (1951), Simón ([1626] 1953), Cuervo Márquez (1956), Broadbent (1964), Arango Ferrer (1965), Restrepo ([1895] 1972), Uricoechea (1984), Camargo (1991) y Quijano (2000), entre otros, se refirieron en sus textos a los habitantes que halló Jiménez de Quesada en la altiplanicie andina como chibchas.

Autores, docentes e investigadores como Pérez de Barradas (1941), Ghisletti (1954), Falchetti y Plazas (1973), Rozo (1984) y Langebaek (2009), entre otros, aludieron a estos habitantes como muiscas, 
de igual manera que lo hace el equipo de investigadores y curadores del Museo del Oro de Bogotá en Botero et al. (2008), quienes identifican a este grupo prehispánico como cultura muisca-guane.

Encontrándose, entonces, con las dos formas en que los autores antes señalados se referían a esta cultura americana, como chibcha o muisca, y recordando lo expresado por Simón sobre el término chibcha que significaba persona, y que identificaba de igual manera a Bacatá como la región en que ellos habitaban (Simón ([1626] 1953, citado por Restrepo [1895], 1972), en este libro se referirá a este grupo indígena con el vocablo chibcha. Además, se ratifica la decisión porque los autores consultados por Acuña, los textos publicados por él mismo, así como la mayoría de los autores investigados y reseñados en este libro, se refirieron al grupo nativo chibcha como tal. En el caso que autores, investigadores y curadores citados se refieran a los muiscas, lógicamente se realiza la referenciación en concordancia con lo publicado.

¿Cuál es el origen de la cultura chibcha? Restrepo ([1895] 1972) sobre su ruta, el momento histórico de su llegada y el número poblacional de inmigrantes, y sostuvo que esta sociedad provino de lo que hoy es México o Centroamérica y que su ruta de ingreso correspondió al noroeste, vía río Magdalena-río Opón. Estos grupos poblacionales lle- garon a establecerse en zonas que posteriormente corresponderían a los cacicazgos de Bogotá, tales como Fusagasugá, Facatativá, Chocontá y Zipaquirá, pertenecientes al dominio del zipa; Guatavita, Guavio, Cáqueza y Ubaque, que harían parte del cacicazgo de Guatavita. Ubaté, Chiquinquirá y Moniquirá, que comprenderían el dominio del cacique de Susa; Tunja, Ramiquirí y el valle de Tenza, que formarían parte del dominio del zaque; y por último, el dominio de Tundama que lo conformarían Duitama, Sogamoso y Soatá. La unión de estos cacicazgos hizo parte de lo que se conoció como el Imperio chibcha.

Explicó Restrepo ([1895] 1972) que las primeras nociones sobre la sociedad chibcha obedecieron a los propios relatos de sus miembros, a las observaciones y reflexiones que realizaban los cronistas a partir de las lecturas de documentos escritos por conquistadores y evangelizadores. Sobre estas instancias primarias es que se concibió la memoria acerca del proceso de conquista, sometimiento y destrucción de la cultura aborigen.

Sin embargo, señaló también que, si bien esta información presenta un propósito de orden estructural, ninguno de los textos consultados provee datos certeros sobre el universo chibcha, ni hechos destacados o situaciones de especial importancia, y que es frecuente encontrar errores o 
Piedras del Tunjo en Facatativa, departamento de Cundinamarca. Fotografía:

Felipe Restrepo Acosta.

Licencia CC BY-SA 4.0, 25 March 2016.

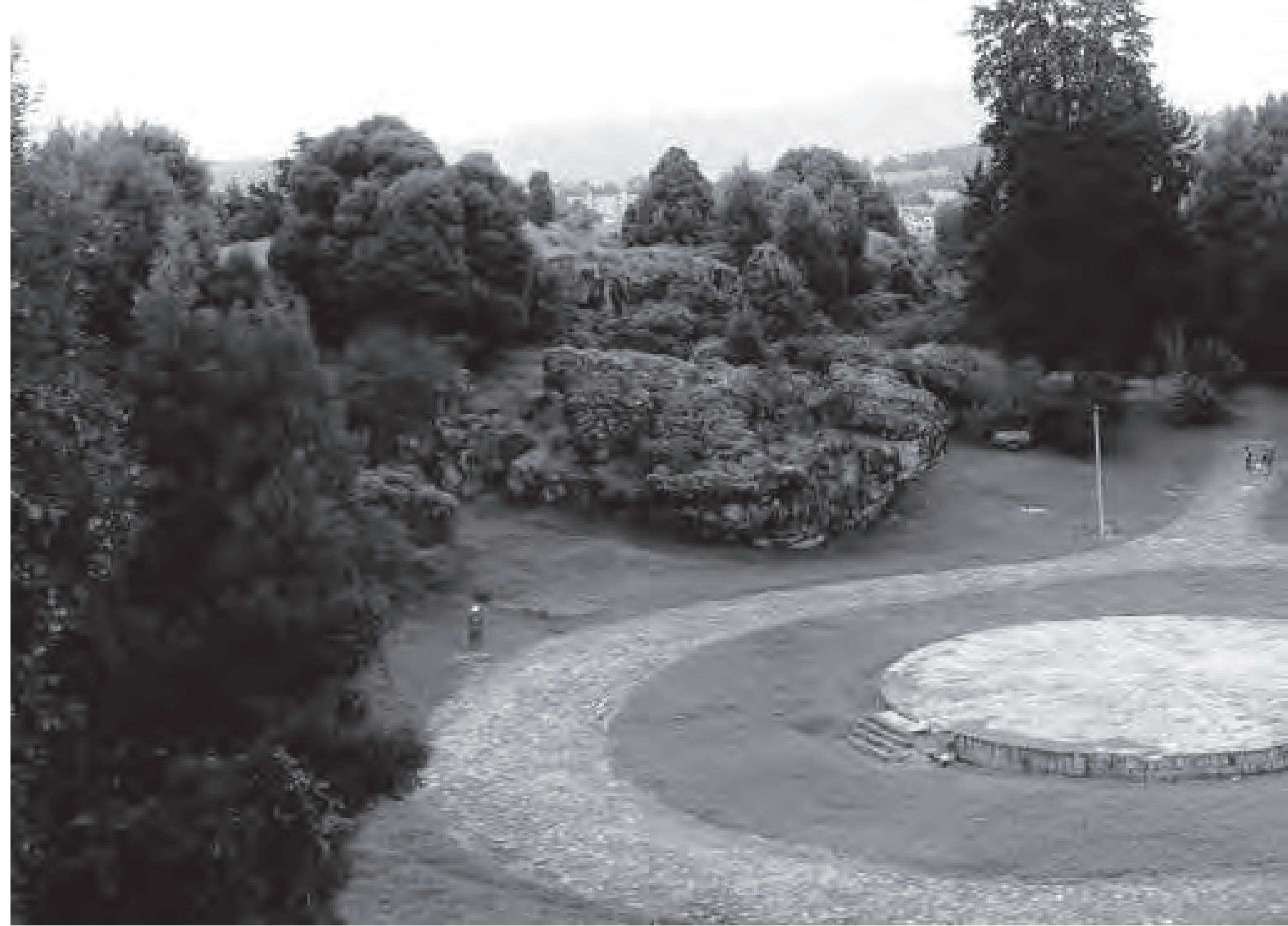




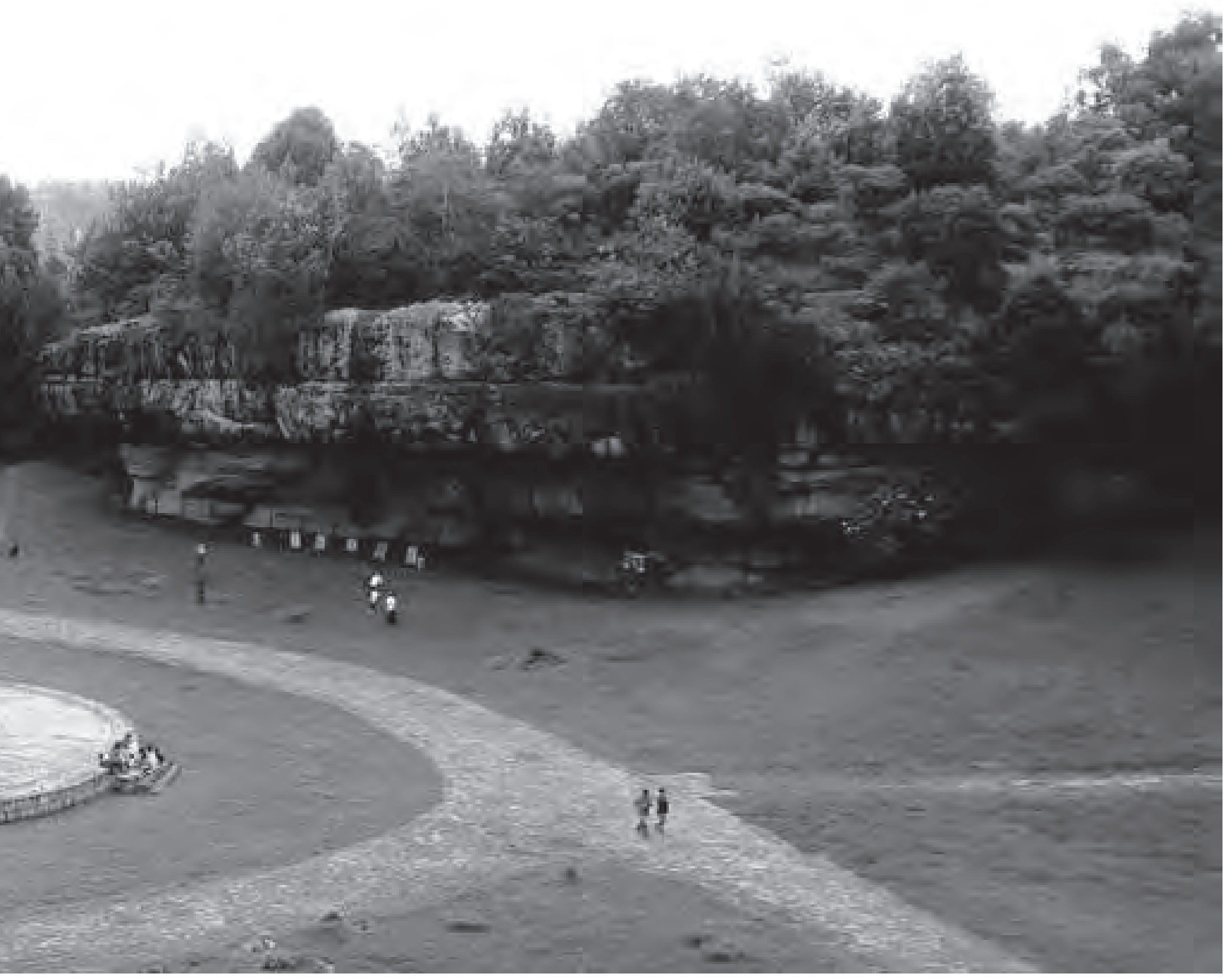


confusiones en la interpretación de hechos, pero que, si se realiza un proceso de confrontación entre los textos, es posible deducir los aciertos y los errores históricos.

Restrepo ([1895] 1972) también puntualizó que otra fuente de estudio aplicable para conocer el funcionamiento de la sociedad prehispánica chibcha es el análisis de su arte y el estudio de sus elementos rituales, decorativos y utilitarios elaborados en materiales como piedra, madera, cerámica, cobre y oro.

Las labores de investigación que se pueden realizar sobre estos objetos, bajo la óptica de las crónicas y la tecnología básica actual como el carbono 14, proveen un complemento importante para conocer su organización social, cultural y religiosa y sus conocimientos técnicos.

Sobre la organización política, social, económica y religiosa chibcha existente al arribar Jiménez de Quesada al altiplano cundiboyacense (1537), Márquez et al. (1975) señalaron lo siguiente. Que si bien existían tres cacicazgos (Sugamuxi, Tundama y Guanentá), los chibchas mantenían dos centros principales de gobierno: el primero en Bacatá, donde regía el zipa, y el segundo en Hunza, donde gobernaba el zaque; su rivalidad y continuas luchas por el poder eran muy conocidas en su momento y algunas escaramuzas entre caciques de menor rango. El zipa gozaba de gran influencia sobre los caciques que seleccionaba para regir en los diferentes cacicazgos, quienes, una vez nombrados, transmitían el mando por herencia materna, lo cual significa que la línea de mando se cedía al sobrino, hijo de la hermana. Si no se presentaba un sucesor directo, el cacique podía seleccionar a su reemplazo dentro de los más valientes guerreros. Los zipas que tenían mayor reconocimiento eran Suganmachica, Nemequene, Tisquesusa y Saguipa, y dentro del entorno de los zaques, se destacaban por su liderazgo Michua, Quemuenchatocha y Aquimínzaque.

La organización administrativa estaba conformada por partes, pueblos y confederaciones; entre las agencias menores de gobierno, sobresalían los consejos confederados que atendían asuntos de guerra y los consejos especiales que, como su nombre lo indica, atendían casos especiales. Respecto de las clases sociales, los chibchas mantenían dos tipos de jerarquías: una civil y otra religiosa. Las instancias civiles, a su vez, se dividían en clases sociales, como pregoneros, uzaques, guechas, tributarios y esclavos. En la religiosa, se destacaban los jeques, que equivalían a los sacerdotes a quienes no se les permitía contraer matrimonio, y cuyo cargo era obtenido por línea matrilineal.

Para ser nombrados como tales, debían habitar desde pequeños en un espacio de caracterís- 
ticas divinas llamado cuca, guardando continuo ayuno (Márquez et al. 1975).

Dentro del universo espiritual de los chibchas sobresalían dos clases de mitos principales: el primero, que tenía que ver con la creación del mundo y del hombre, constaba de dos subdivisiones: Chiminichagua, a quien se le atribuía la creación de la luz, y Bachué, a quien se le conocía como la creadora de la raza. El segundo mito, que hablaba de los dioses civilizadores, tenía una subdivisión en dos conceptos: Bochica, quien les enseñaba sobre la importancia de practicar el bien y a trabajar los textiles, era también considerado como la deidad que los salvaba de una inundación; y Huitaca era conocida como una mujer que los inducía dentro de los caminos de los vicios y del mal (Márquez et al. 1975).

La responsabilidad de los aspectos religiosos chibchas radicaba en una casta de jeques de tipo sacerdotal, la cual, según el mito, fue constituida por Bochica, y estaba a cargo del cacique de Sogamoso, cuya órbita religiosa cubría todo el grupo humano de la cultura chibcha e intercedía por los hombres ante los dioses. Entre sus obligaciones, se destacaban las labores relacionadas con los sacrificios rituales; eran los anfitriones de las fiestas ceremoniales y poseían el monopolio del comercio de la coca, de donde se originaba su sustento.
En segunda instancia, también existían los mohanes (brujos, curanderos, prestidigitadores y hechiceros). Sobre los sacrificios se puede afirmar que se ofrecían al dios Sol en su templo de Sogamoso niños criados en un entorno sagrado dedicado al sol; cuando estos niños cumplían diez años, se daba inicio a un proceso de selección y preparación. Una vez cumpliesen con los requerimientos rituales planteados por el dios civilizador Bochica, y hubiesen llegado a la edad de quince años, serían inmolados. El resto de los sacrificios se realizaba con animales, joyas y esmeraldas (Márquez et al. 1975).

Con el objetivo de aclarar en qué consistía la cosmogonía y el simbolismo ritual de una sociedad prehispánica, se tendrá en cuenta lo expuesto por Botero et al. (2008), para quien el modelo de pensamiento indígena lo constituía un gran sentimiento de espiritualidad, que se traducía en otorgarles una representación sagrada al universo, a su territorio, a la sociedad y a sus creaciones materiales, mediante vínculos que trazaban una relación cercana entre los hombres y sus ancestros, elemento esencial para perpetuar sus tradiciones. En el caso de la cultura chibcha, los caciques fueron los encargados de perpetuar, transferir y remozar las representaciones cosmogónicas. El proceso educacional de estas personas iniciaba desde una temprana juventud, durante la cual se trataban te- 
mas como la mitología, los usos de las plantas sagradas, el vocabulario, las gestualidades y la importancia de los objetos sagrados. Se buscaba que los caciques transmitieran a su comunidad los significados y valores de las representaciones cosmogónicas y así se mantuviera el normal desarrollo de la naturaleza, se preservara la espiritualidad y la prosperidad de su sociedad.

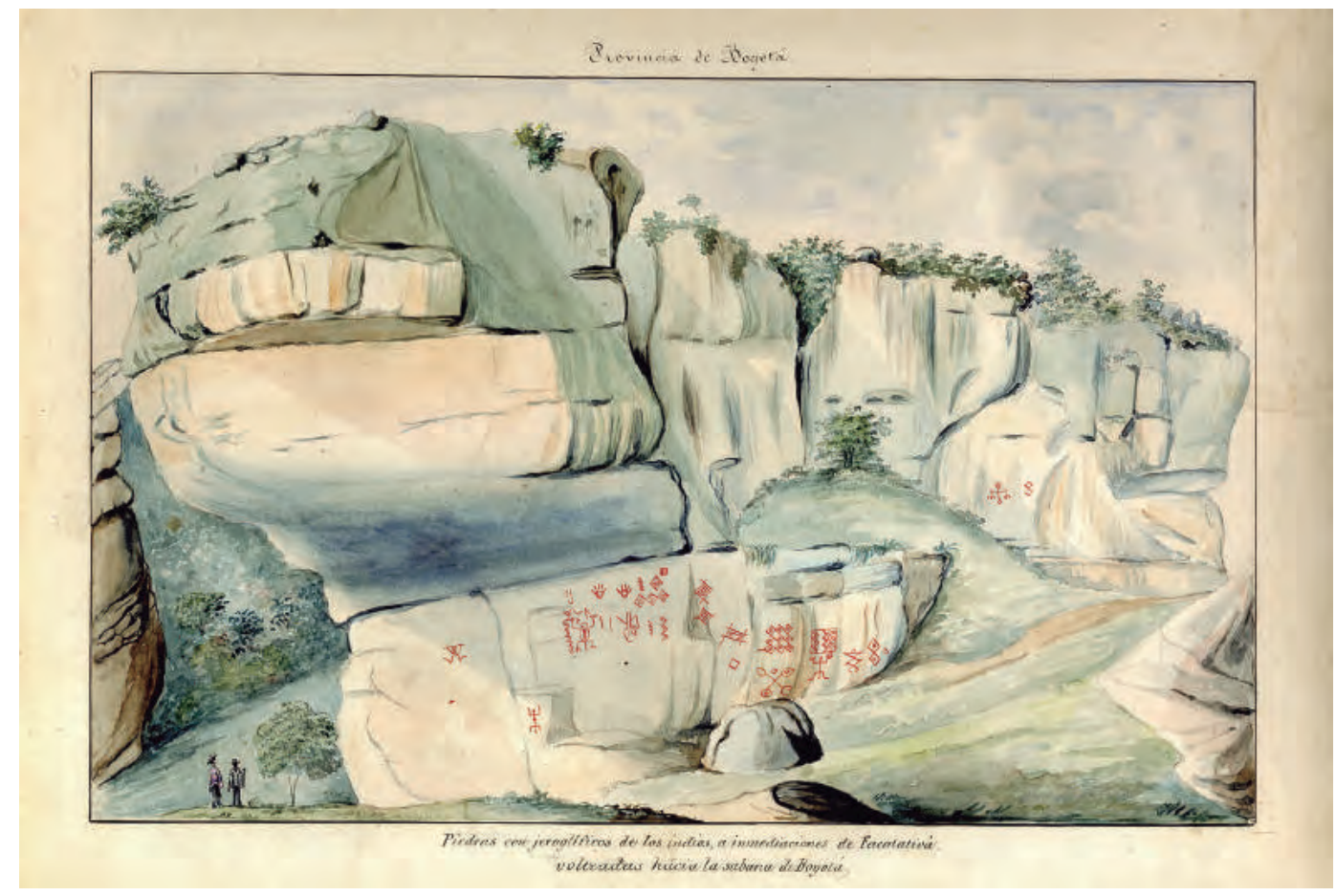

Piedras con jeroglíficos de los indios, provincia de Bogotá. Manuel María Paz (1853-1858) Acuarela. Fuente: Obtenida el 15 de octubre de 2018, de Achttps:// www.wdl.org/es/ item/9108/ 
mas como la mitología, los usos de las plantas sagradas, el vocabulario, las gestualidades y la importancia de los objetos sagrados. Se buscaba que los caciques transmitieran a su comunidad los significados y valores de las representaciones cosmogónicas y así se mantuviera el normal desarrollo de la naturaleza, se preservara la espiritualidad y la prosperidad de su sociedad.

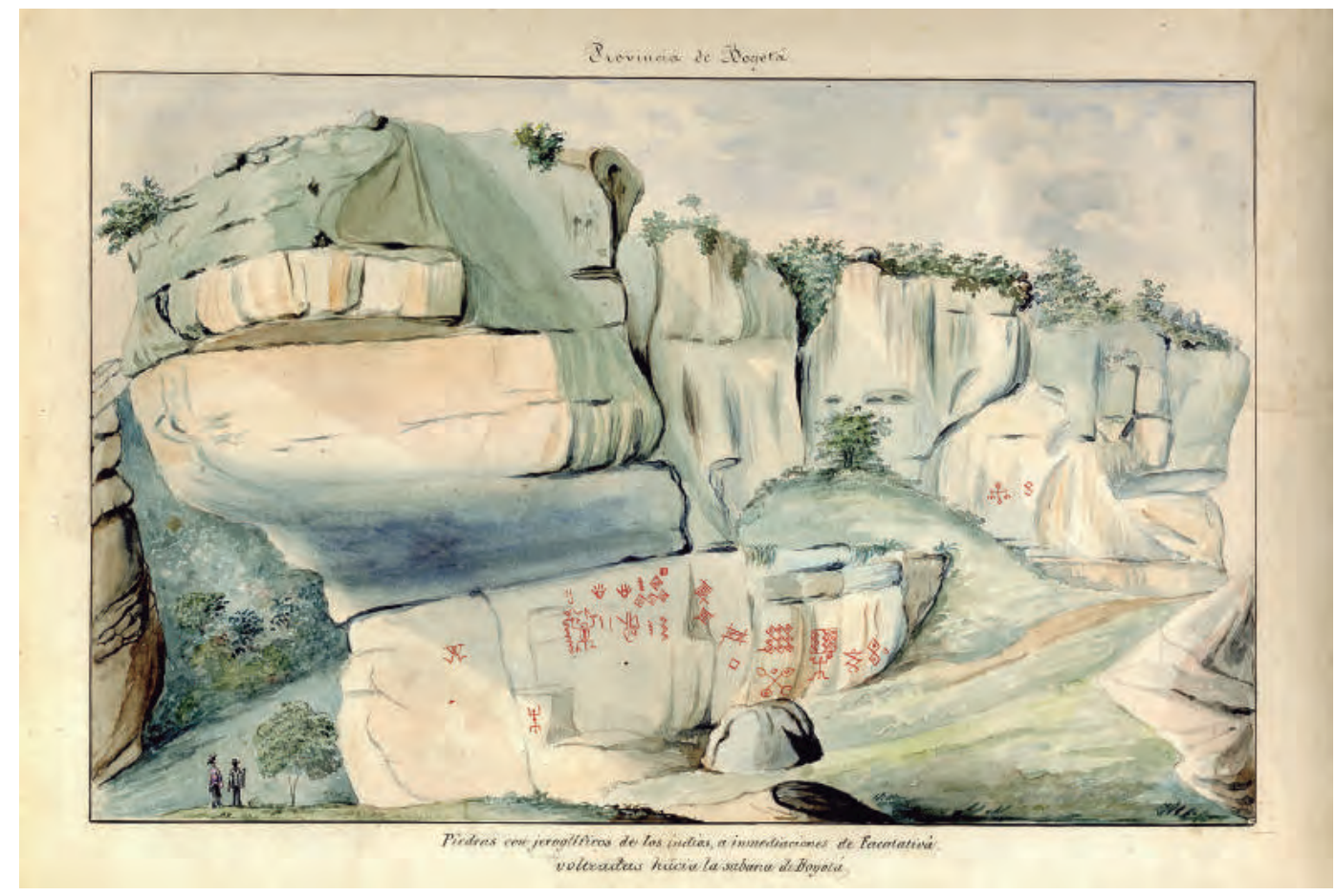

Piedras con jeroglíficos de los indios, provincia de Bogotá. Manuel María Paz (1853-1858) Acuarela. Fuente: Obtenida el 15 de octubre de 2018, de Achttps:// www.wdl.org/es/ item/9108/ 
Los ancestros

de Luis Alberto

Acuña y su

metodología

de estudio

\begin{abstract}
uan Friede (1946) anotó que Acuña, a través de las páginas de las crónicas de la conquista, tomó conciencia acerca la de vulnerabilidad de la situación del aborigen americano, por cuanto era poseedor de una sólida cultura, que sorprendió por igual a conquistadores, evangelizadores y cronistas, ya que, con su música, danza, pintura, escultura y orfebrería, obtuvieron un importante nivel de perfeccionamiento entre las culturas americanas. Así es como la mitología, la organización social y las costumbres de estas sociedades prehispánicas distaban del imaginario europeo que los identificaban como pueblos bárbaros, salvajes y crueles.

Friede (1946) sostuvo que las creaciones artísticas prehispánicas para Acuña no solo encarnaban la necesidad de ser estudiadas, sino que, por constituirse en expresiones visuales de la vida normal de las indias occidentales, contenían elementos que, además de hacer parte de instancias como la arqueología, poseían un gran coste presente para constituir un auténtico arte colombiano contemporáneo, en otras palabras, un arte americano.
\end{abstract}


Del texto de Friede mencionado, vale la pena resaltar que el ascendiente de Acuña, don Francisco Miguel de Acuña y Angulo, fue encomendero de los pueblos de Güepsa y Cerinza en 1668, y que su nieto don Francisco Miguel de Acuña, quien heredó de su abuelo el inmenso latifundio, presentó una queja al capitán general del Nuevo Reino de Granada en la que le informaba:

[...] sacan los indios de los dichos pueblosy se los llevan con sus familias, dos, tres, cuatro y seis leguas apartados, para tenerlos en continuos servicios de trapiches [...], asi son sumamente molestados [...], faltan del pasto espiritual de su alma, de que todo el año carecen. (9-10)

Este pensamiento es citado para estipular que el linaje de Acuña desde el siglo XVII tuvo contacto con los aborígenes americanos y que, de acuerdo con la mención, podría existir una heredada conciencia social por la causa indígena, argumento por el que es posible cuestionarse si pudo ser posible que Luis Alberto Acuña haya dedicado la mayor parte de su vida artística a trabajar temáticas prehispánicas y campesinas, motivado en parte por esta herencia cultural ancestral.

Para dar respuesta al anterior interrogante, se cita el discurso pronunciado por Acuña en sep- tiembre de 1955, al tomar posesión como miembro numerario en la Academia Colombiana de Historia. En el documento titulado "Los Acuñas en la Nueva Granada", publicado en el boletín 493 de Historia y Antigüedades de la Academia, se encuentra el siguiente texto:

Y en la nómina de servidores, así en la Real Audiencia como en el Virreinato continúa acrecentándose, como bien a las claras nos lo hace ver la siguiente cronológica enumeración: [...] Francisco Fernández y Magallanes de Acuña (1629), Gobernador de los Muzos y Colimas, Francisco Franco de Acuña (1640), Gobernador de los Panches, Miguel de Acuña y Angulo (1668), Regidor y Justicia Mayor de Tunja y Encomendero de Guepsa y Ceniza [...] Lo que en este discurso queda consignado es el fruto de una investigación adelantada con la saludable curiosidad de saber cómo y de dónde procedían aquellas gentes cuyo apellido llevo $y$, lo que es más importante, de qué manera supieron cumplir ellas sus triples e indeclinables deberes para con Dios, con la sociedad y con la patria. Elocuente respuesta a esta pregunta fue el hallazgo entre otras, de una virtud común a todos ellos: el servicio de sus semejantes, a lo que es lo mismo aplicando la fórmula 
cristiana: el amor y provecho al prójimo; virtud capital, suma y compendio de todas las demás y sin la cual no es posible merecer el recuerdo de los semejantes ni menos aún ser grato a los ojos de Dios. (Acuña 1955b, 683-688)

Respecto de la manera en que Acuña estudió el arte precolombino con el objetivo de publicar sus hallazgos, y a partir de ellos realizar las representaciones plásticas de las deidades de los chibchas y así poder contribuir artísticamente al discurso bachué, se cita el siguiente texto de Acuña (1942a):

Dos son los documentos fehacientes, dos los indispensables recursos que guían nuestros pasos en el tremedal de la prehistoria, al intentar, en virtud de un ordenado proceso, escudriñar el origen y fijar las características de nuestro arte indígena: el material plástico o arqueológico, y el material literario o histórico. El primero lo constituye la gran abundancia que guardan los museos, las colecciones particulares y los que día a día se van descubriendo. El segundo nos los proporcionan principalmente los cronistas de las épocas del descubrimiento, de la conquista y de la colonización con tan rica abundancia de datos que a veces exceden a cuanto nos es dable aprovechar [...] es por esto por lo que invocamos [...] la acuciosidad de Simón. (3-4)

Acuña (1942a) indagó sobre la orfebrería chibcha, y manifestó que su interés radicaba en el plano estético y en el contenido de los relatos de los cronistas, de los cuales emergían la verdad, la emoción y la vida. Sin embargo, sostuvo que una pieza prehispánica presenta para el investigador de igual manera un interés arqueológico, puesto que el objeto analizado puede contener en sí elementos de gran importancia.

En virtud de lo anterior, afirmó que se deben realizar estudios cruzados de orden histórico, arqueológico, antropológico y estético, con el fin de obtener resultados que puedan ser relacionados entre sí y así poder llegar a conclusiones a partir de los hallazgos individuales que puede brindar cada disciplina.

Así es como está concebida y planteada la estructura metodológica bajo la cual Acuña investigó sobre la diversidad de los elementos que conformaban las expresiones que hicieron parte del universo cosmogónico chibcha, cuyos resultados consignó en su libro El arte de los indios colombianos (Ensayo crítico e histórico), ediciones de 1935 y 1942.

Acuña (1935) se refirió al desconocimiento existente a mediados de la década de 1930 sobre 
las razones por las que se hallaban más representaciones de un jerarca que de una deidad en el arte chibcha. En virtud del siguiente pensamiento, es posible que Acuña haya fundamentado la búsqueda de temas y el tratamiento plástico que implementó en la realización de su arte sobre la mitología chibcha:

Porque acontece que no existe una cabal concordancia entre los bien definidos elementos que integran el panteón de los chibchas y las figuras antropomorfas que modelaron. No aparece entre ellas la representación del anciano Bochica, de traje talar y luengas barbas, ni de Chibchacún en su actitud característica de sostener la tierra sobre sus hombros, ni de ninguna otra de sus divinidades tutelares; en tanto que con regular frecuencia aparecen barros cocidos en los que fácilmente se reconoce a los jeques o sacerdotes y a los caciques o principales señores.

$Y$ como es seguro, porque así nos lo afirman los cronistas [...] se nos ocurre pensar que los chibchas harían con carácter religioso, una selección rigurosa de los materiales al moldear a los humanos en barro y a los dioses en oro, y siempre dentro tipos en extremo convencionales.
También en piedra hicieron algunas representaciones de sus divinidades pues el padre Simón al referirse a los viajes de Bochica, informa que los indios guanes esculpieron su retrato "aunque muy a lo tosco, en unas piedras que todavía hoy se ven".

Cualquier canon de proporción e indicación anatómica o intención naturalista está proscrito en estas esculturas chibchas, que frecuentemente pecan contra toda lógica concepción de la figura humana. Y sin embargo la estilización de los rostros de estas imágenes es tan apacible y singular, que revela en aquellos artífices primarios un muy alto acierto al uso de los recursos figurativos más simples. Por medio de grandes planos, incisiones horizontales y un fino relieve que indica la nariz, lograron dar a los rostros que modelaron una perfecta expresión de serenidad y hasta de placidez interior. (1942a, 40-42)

En "Notas para un ideario autobiográfico", Acuña (1957-1958) señaló que el resultado de sus años de educación académica en París, Madrid,

Italia y Alemania, además de una situación afectiva que sostuvo en Castilla, se constituyeron en las instancias por las cuales tomó 
la decisión de realizar un arte en el que las figuras avasallaran por entero la superficie disponible; en que los elementos constitutivos del cuadro se hallaran arbitrados con rigorismo arquitectónico, ocupando siempre el primer plano, con prescindencia casi absoluta de la profundidad espacial, y en el color, arbitrado como en mosaico por toques y no por puntos ni otra manera, fuese no sólo importante elemento ornamental por su poder vivificante, sino también materia ópticamente moldeable, estructurada con la más rotunda plasticidad. Quedaban así planteadas las características del estilo que habría de informar la producción de veinticinco años de mi vida, características a la cuales habría que añadir una más, recibida de las láminas primero y más tarde afianzada delante de los originales: la de los fresquistas mejicanos Orozco y Rivera, cuyo contenido indigenista me resultó especialmente atrayente. (189-190)
De acuerdo con lo anterior, es posible sintetizar que Acuña, interesado por la situación del aborigen americano, investigó, publicó y más tarde reflejó en su plástica los elementos de dación de sentido de la cultura chibcha, como resultado de sus reflexiones sobre la situación de desprecio y olvido a que había sido sometido el indio desde la Conquista, con el objetivo de rendirle homenaje a una sociedad que obtuvo un nivel alto de desarrollo cultural. Así es como se dedicó, entonces, a profundizar en los resultados de sus investigaciones, a publicar su pensamiento y a proseguir con el desarrollo de su plástica sobre el tema del universo cosmogónico chibcha, el cual representó en las diferentes facetas de su arte, que lo situaron como el único artista que trabajó en su obra -tanto en una composición que comprende una figura individual como en la disposición de un conjunto de figuras - su visión idealizada de casi la totalidad de las deidades, mitos y símbolos que hicieron parte de la cosmogonía chibcha. 


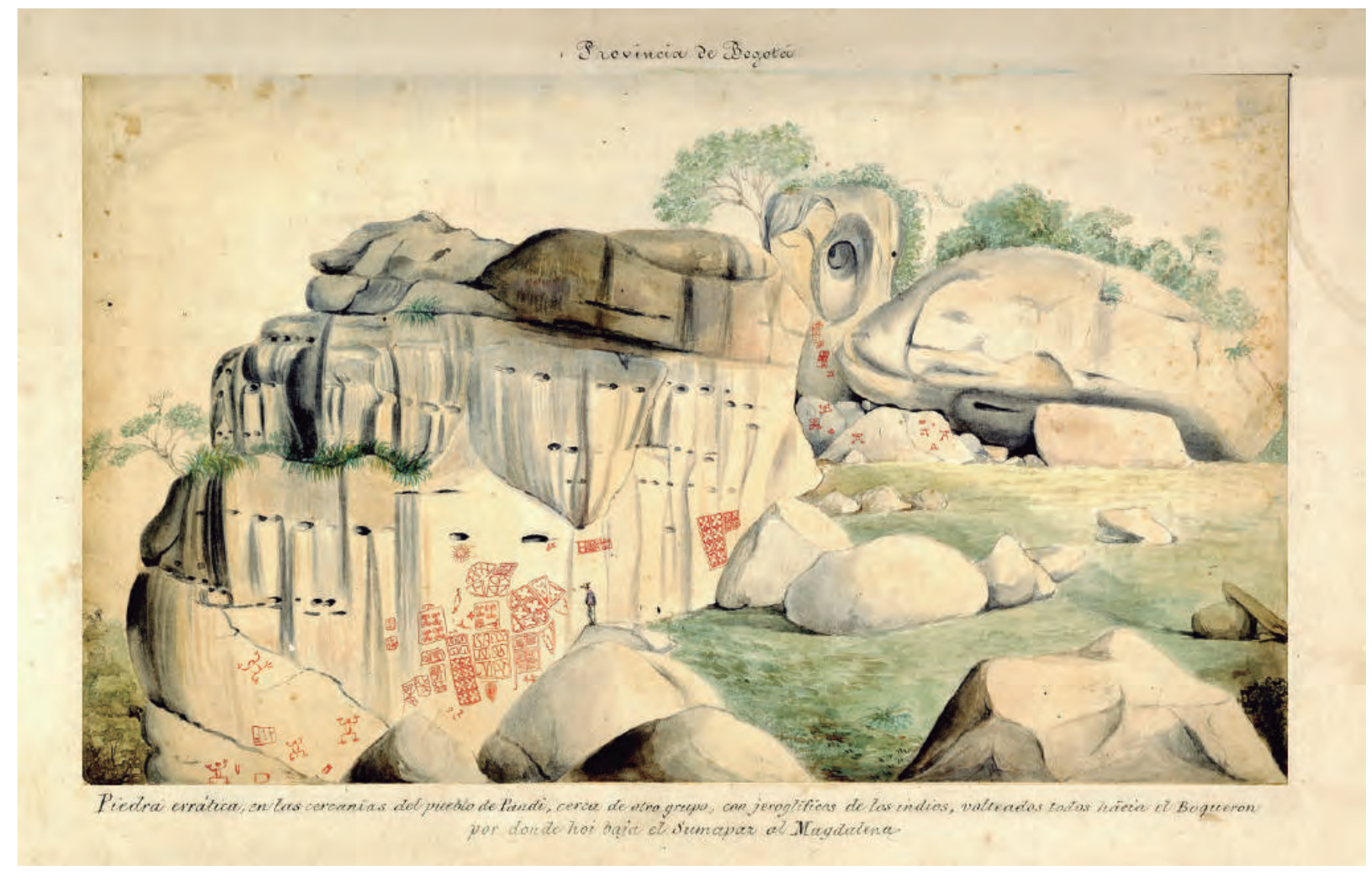

Grupo de piedras con jeroglíficos cerca de Pandi, provincia de Bogotá. Manuel María Paz. (1853-1858) Acuarela. Fuente: obtenida el 15 de octubre de 2018, de https://www.wdl.org/es/item/9112/ 


\section{Teorías}

publicadas por

Luis Alberto

Acuña y

pensamientos

de otros autores

en torno a la

cultura chibcha

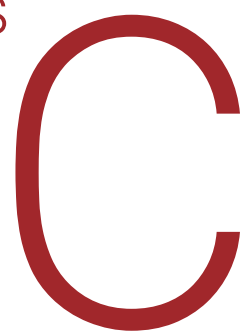

on el objetivo de iniciar al lector en el pensamiento de

Acuña en torno a la cosmogonía chibcha, se transcribe este texto de su libro El arte de los indios colombianos (Ensayo crítico e histórico) de 1935:

En su más elemental modalidad conviene considerar nuestro arte indígena como uno de los productos de la lenta formación de la experiencia del hombre primitivo frente a las múltiples y variantes circunstancias de la naturaleza: perplejo ante todo lo patético, extraño y mutable; impotente ante las fuerzas inexplicables del cosmos, en sus horas de angustiada meditación, intuyó la Divinidad y creó la religión, pretendió conjurar el dolor y la muerte con el extraño ritual de un oscuro chamanismo; ideó multitud de símbolos, y redujo a formas tangibles, extrahumanas e ingentes las deidades que forjó su aterrada o pueril mentalidad, o su fanática ortodoxia. Pues el Arte y Religión aparecen como creaciones congénitas, nacidas al calor de la sublime trinidad del instinto, la intuición y la sensibilidad. (8-9) 
En La civilización chibcha (1922), Triana mencionó que este pueblo se consideraba a sí mismo como el primer habitante de su territorio e imaginaba ser hijo de la tierra; su deidad mayor se llamaba Chiminichagua (ser bueno), llamado el señor de todas las cosas, creador de la luz y el sol, la luna y todos los elementos que conforman lo bello de la tierra. Chiminichagua no poseía ningún tipo de imagen que lo representara como tal, como tampoco se le rendía culto, pues dentro de las creencias chibchas se encontraba que se debía adorar al sol (Sua), por ser una criatura con mucha claridad, y a la luna o Chía, a la que se identificaba como la compañera del sol. Bajo estos antecedentes, apareció Bochica en la figura de un extranjero barbado a quien los chibchas interpretaron como un civilizador y maestro. Bochica, se encargó de instruirlos en las técnicas de hilar y tejer el algodón; entre sus enseñanzas, se encontraban además del arte de la bondad, como ayudar a los pobres y la importancia de llevar una vida austera. De igual manera, Bochica les enseñó sobre la inmortalidad de las almas y acerca de los premios o castigos que recibirían según sus acciones en la Tierra (Triana 1922).

Triana (1922) afirmó que, entre los entes del mal, se destacó Huitaca, quien bajo la forma de una mujer bella y joven inducía a los aborígenes chibchas en el arte de la "buena vida", destacan- do los placeres, la danza y el abuso de las bebidas embriagantes. Bochica, quien observó desde las alturas la destrucción de su obra de reforma moral y de las buenas costumbres, la convirtió en lechuza, condenándola a aparecerse solo en las noches. Sin embargo, la población chibcha quedó muy afectada por las enseñanzas de Huitaca y su comportamiento no reflejó sino oscuridad, desconociendo en todo sentido los preceptos de Bochica. Así es como la deidad Chibchacún, con la ayuda de Huitaca, decidió hacer desembocar los ríos Bogotá y Tibitó en el cauce del río Funza lo que provoco que se inundara la sabana, teniendo los chibchas que refugiarse en las montañas donde no podían cultivar la tierra. Desesperados por esta situación, apelaron a la bondad de Bochica, seduciéndolo mediante clamores, penitencias y sacrificios.

El extranjero blanco conmovido por la petición se colocó sobre el arcoíris, al que se le identificaba como Cuchaviva, y lanzó su vara sobre el sitio que hoy se conoce como el Salto de Tequendama, rompiendo los peñascos para que de esta forma desaguaran las aguas represadas.

Según Julio Carrizosa Umaña (2014), en el periodo Terciario se formaron las cordilleras que nacieron de las profundidades del mar; esta afectación marina que tuvo lugar en el oriente del territorio se conjugó con los accidentes tectónicos pro- 


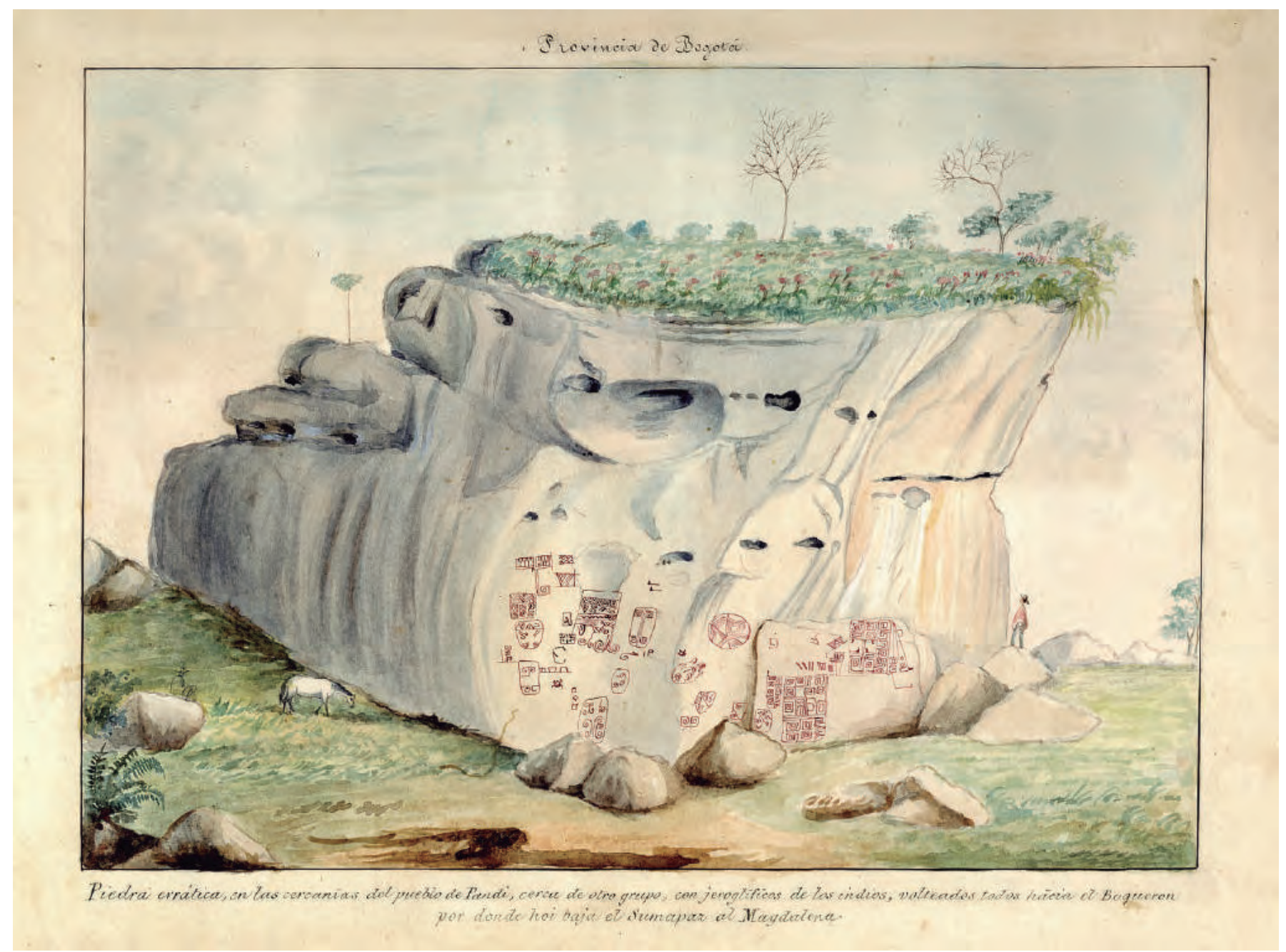

Piedra errática, en las cercanías del pueblo de Pandi, con jeroglíficos de los indios, provincia de Bogotá. (1853-1858) Manuel María Paz. Acuarela. Fuente: obtenida en octubre 15 de 2018, de https://www.wdl.org/es/item/9107/ 
pios del periodo y formaron un espacio en el que las aguas marinas se represaron, las cuales, con el paso de miles de años, fueron reemplazadas por "lagos, ciénagas, pantanos y ríos que conducian las aguas lluvias" (81). Los diferentes microclimas resultantes de los anteriores cambios en el medio ambiente permitieron que en grandes periodos se desarrollaran muchos microorganismos que en un lapso de varios millones de años se convertirían en las diferentes especies que hoy conocemos. "La lluvia en Colombia excede promedios internacionales por cuanto es seis veces la medida global, y la mitad de esta cifra comprende el nivel que corresponde a América Latina" (Ideam 2010, 69).

Lo anterior llama la atención acerca de la complejidad del territorio colombiano respecto de su riqueza ecológica, puesto que los chibchas se ubicaron en un espacio geográfico que comprendía abundantes recursos hídricos, al igual que de fauna y flora, y así se posibilitó la creación de una cosmogonía basada en el agua, como la que estructuraron para ser guiados en su espiritualidad. Como resultado de los pliegues formados en la tierra, el agua lluvia encontró sus nichos que permitieron la formación de lagunas, como es el caso de la que se conoce como Iguaque, que hoy hace parte del Santuario de Fauna y Flora de Iguaque, al igual que la laguna de Guatavita, que conforma el Parque Na- tural Laguna del Cacique de Guatavita. En los entornos hídricos mencionados y en otros lugares que hacen parte del lugar de asentamiento de la cultura chibcha, se concibieron aspectos de su religiosidad, tales como el proceso de procreación de la sociedad chibcha, atribuido a Bachué e Iguaque, y la realización de la ceremonia del cacique de Guatavita. Al agua de las lagunas se le otorgó el nombre de una deidad, como es el caso de Sía, a las ranas se les atribuyó la representación del alma de los chibchas y a las serpientes el papel de guardianas de las lagunas. Las lluvias, en conjunción con el sol, permitieron el fenómeno óptico y meteorológico del arcoíris; a este espectro de frecuencias de luz los chibchas le otorgaron el nombre de Cuchaviva, al que las mujeres encintas le otorgaban elementos de ofrenda, con el objetivo de facilitar su proceso de fecundación. Los accidentes tectónicos mencionados pudieron permitir la creación de otros mitos chibchas, como el referido a un ser extranjero barbado, que por medio de su vara rompió unas rocas y permitió que la sabana de Bogotá desaguara el agua que la inundaba, debido al represamiento formado por los cauces de los ríos Bogotá y Tibitó, producido a causa de los repliegues que conformaban la estructura física de aquella zona.

Según Carrizosa (2014, 91), "las características físicas y biológicas del territorio fueron una 
novedad para los primeros caminantes que llegaron a América del Sur desde Asia", grupos que se distinguieron por poseer diferentes lenguas y organizaciones sociales, adaptaron su forma de vida de acuerdo con lo que les proveía uno de los ecosistemas más biodiversos del planeta.

De acuerdo con Restrepo ([1895] 1972), los chibchas tenían muchos sitios de adoración situados en montes, caminos, ríos y ciertas lagunas sagradas. Ellos ingresaban a estos lugares con el mayor respeto y devoción para realizar su culto y hacían reverencias, con la cabeza baja y mirando hacia el suelo, situación que se repetía cuando salían del lugar. ¿A quién le realizaban devociones estos aborígenes? Al cacique respectivo, al sol, a la luna y a sus dioses. ¿Qué buscaban con estas plegarias? Todo tipo de favores, como los que tienen que ver con las necesidades de agua, las cosechas, el alivio de enfermedades, etc. Por otra parte, cada indígena poseía un dios en su casa y llevaba consigo siempre pequeñas versiones del ídolo ofrendatario de su devoción, con el fin de no encontrarse nunca desamparado: tenían una deidad para cada necesidad humana. Mencionaba fray Pedro Simón ([1626] 1953) que los indios, al ver a los europeos, huyeron llenos de temor hacia los montes cercanos, y que cuando tuvieron un primer acercamiento con los conquistadores, les obsequiaron variados tipos de regalos, como las mantas que tenían características sagradas, esmeraldas u objetos en oro, que eran utilizados como elementos ofrendados, al igual que alimentos, con el objetivo de no ser dañados por estos seres de desconocido origen. Una vez se estableció el contacto con aquellos visitantes, tuvo lugar el siguiente acontecimiento:

[...] al fin sería la dicha u otra la razón, de verse los indios sin barbas y a los nuestros con ellas se causaban admiración y de estos y su blancura muy grandes errores como estos de Guachetá los tuvieron. Porque luego concibieron en su pensamiento que hombres de aquella manera y traza no podían ser hijos de otro que su gran dios el sol, porque llamándose al sol Sua, a los españoles llamaban Sué, que quiere decir hijo del sol. Y pasando estos guachetáes, adelante con su ignorancia la tuvieron en decir que los enviaba el sol, sus hijos para que castigaran a ellos y a los demás indios de sus muchos pecados de que le tenían ofendido y para que tuvieran mayores fuerzas había hecho aquellos animales tan veloces 0 aquellos hombres con cuatro pies y talle tan nunca visto, entendiendo como los demás hasta alli que todo era de una pieza hombre y caballo. (Simón [1626] 1953 1:273-274) 
La laguna de Guatavita, departamento de Cundinamarca. Fotografía: HJCU-

BILLOS. (2014) Fuente: Obtenida en octubre 15 de 2018, de https://commons.

wikimedia.org/wiki/File:Diosa_Guatavita.jpg Licencia CC-BY-SA-4.0

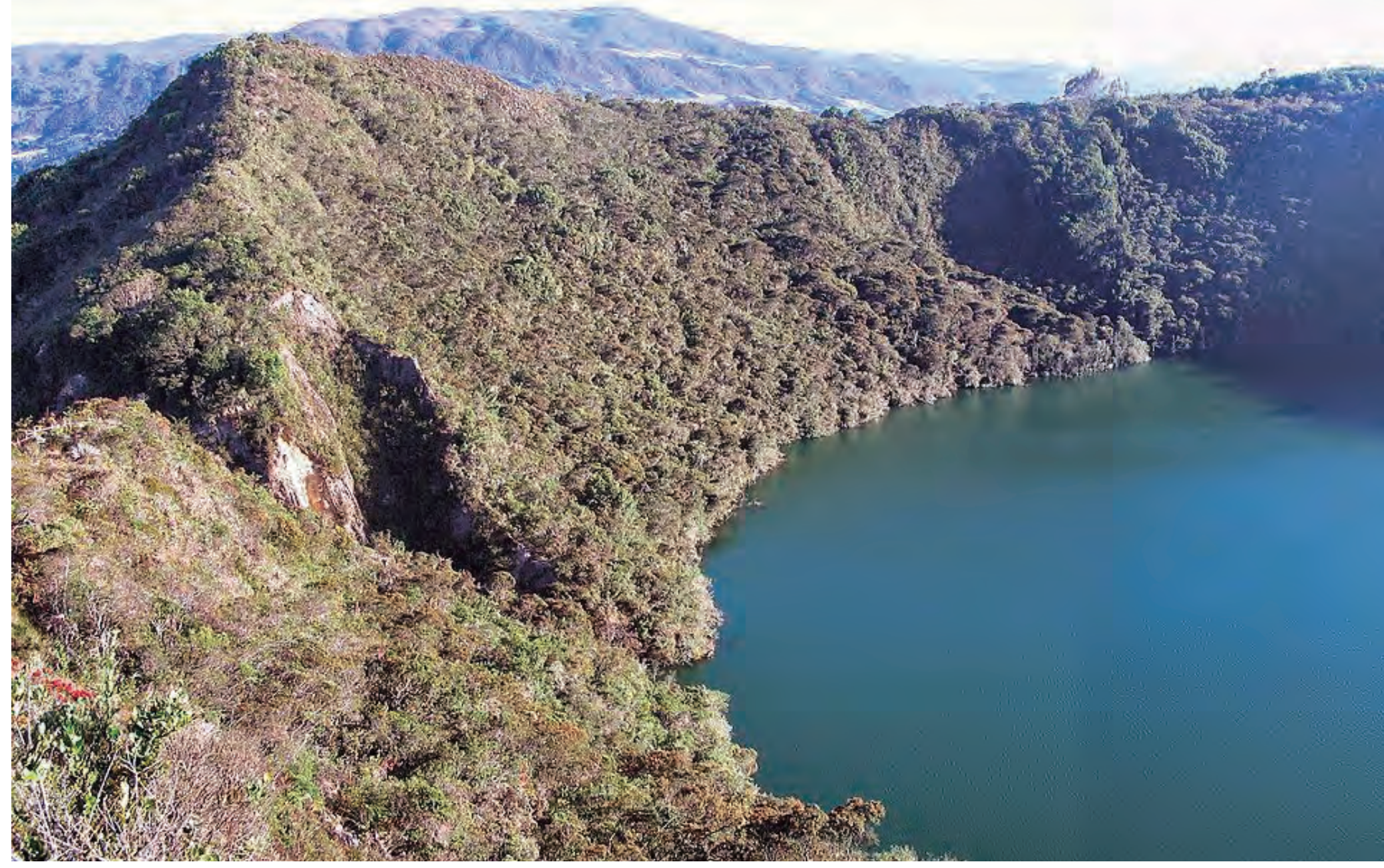


De acuerdo con lo planteado por Márquez et al. (1975), es posible afirmar que una vez los españoles se familiarizaron con los aborígenes americanos y con su territorio, estos últimos presentaron pequeñas batallas y toda suerte de emboscadas, con el objetivo de bloquear el recorrido de los dominadores. Es en ese sentido que se destacaron los caciques de Zaquezazipa, Quemuenchatocha, Aquimínzaque, Tundama, Tisquesusa y Nemequene, como los principales defensores de la sociedad chibcha.

Arango Ferrer (1965-1986) sostuvo que los cronistas se constituyeron en las fuentes primarias para indagar sobre los periodos de Conquista, evangelización y Colonia, así como sobre las culturas prehispánicas. A Arango Ferrer le llamó especialmente la atención lo sucedido en el primer encuentro entre los dos mundos, en el que conquistadores y evangelizadores, primeros protagonistas del contacto, tuvieron pocas técnicas de procedimiento, para conocer cómo era el pensamiento del aborigen americano, respecto de su cosmogonía, organización social, política y económica, debido a que los españoles ya venían con ideas preconcebidas sobre las acciones que debían adelantar, en parte por su vocación evangelizadora y por sus afanes de conquista y riqueza. Por esta razón, es difícil conocer que por medio de la tradición oral no hayan variado de una forma u otra los contenidos de aquellos recuentos históricos y crónicas de evangelizadores. Por esto, se considera de especial relevancia reflexionar sobre la posibilidad de que, por ejemplo, el zipa Tisquesusa (señor de Bacatá, asesinado por soldados españoles en una emboscada, y quien evitó por todos los medios posibles someterse a los designios de Jiménez de Quesada), o el cacique Quemuenchatocha, hubiesen podido entablar un diálogo con los conquistadores, para hablar sobre el origen de sus ancestros. O en el caso de Sugamuxi, máximo jerarca de los chibchas y los jeques poseedores de la memoria cultural ancestral, hubiesen podido narrar a los conquistadores la historia chibcha, con sus dioses y héroes. Es, de esta manera, como se hubiese podido conocer de mejor forma el universo de esta sociedad prehispánica, el cual se encontraba organizado dentro del perfil de una cultura y era poseedor de una sabiduría metafísica.

Acuña (1965-1986) estimó que el surgimiento del arte prehispánico coincidió con la primera época de la Edad Media europea, y sitúo a los chibchas en los altiplanos andinos, donde dieron fin a su proceso migratorio. Sostuvo que, con el paso del tiempo, esta sociedad fue forjando sus tradiciones, constituyendo sus instituciones, desarrollando su arte, es decir, estableciendo su cultura. Al 
referirse a los trabajos realizados por los chibchas en arcilla, Acuña (1965-1986) señaló que los vasos cinerarios representan manifestaciones antropomorfas, cuyos diseños son proyectados antes de ser ejecutados. Afirmó también que en los trabajos en cerámica se pueden observar figuras humanas voluminosas, que poseen rasgos de gran anchura en la cabeza y en el tronco, con brazos y piernas que se resaltan por su delgadez y que conforman el cuerpo del elemento utilitario. Y acerca de los rostros puntualizó que su concepción responde a un estereotipo, cuya estructura base es la nariz, en la que los brazos constituyen las cejas, mientras los ojos y la boca son incisiones horizontales apenas sugeridas. De igual manera, la forma de los párpados y los labios, que se resaltan por su relieve, corresponden a un trazo horizontal.

Sobre estos rasgos escultóricos de la cerámica chibcha, Acuña reflexionó y aclaró que ni siquiera la representación de los ojos "ni la nariz, ni la boca, así estilizados corresponden al tipo etnosomático del chibcha, con el cual solo se avienen lo ancho y plano del moldeado de esas caras, por lo demás denotativas de una fría e impenetrable expresión" (86-87).

Acerca de los rasgos de la indumentaria chibcha, Acuña (1965-1986) indicó que la escultura figurativa chibcha hace posible identificar las re- presentaciones de los caciques y deidades, pues aparecen allí instrumentos de jerarquía. Sostuvo que es posible observar elementos como gorros, collares, narigueras, pectorales y bandas anchas que sobresalen sobre el pecho y los hombros, en los que se hacen visibles diseños geométricos. Y aseveró que los objetos realizados en piedra, barro cocido y metales, al ser manufacturados por los aborígenes americanos, se convierten en elementos de estudio sobre el nivel de evolución cultural logrado por estos artistas.

En torno al tema de los trabajos realizados en orfebrería, Acuña (1942b) resaltó el talento y la habilidad de los orfebres chibchas, puesto que el oro bruto trabajado y convertido en joyas y exvotos era de magnífica calidad, originalidad y diseño.

Asimismo, manifestó que los mejores artesanos pertenecieron al cacicazgo de Guatavita, donde habitaron cerca de tres mil orfebres en tiempos de la llegada de Sebastián de Belalcázar que venía del sur, y de Gonzalo Jiménez de Quesada que procedía del norte, en busca ambos del famoso Dorado, que ellos imaginaban en la forma de oro bruto fundido en figuras macizas de gran tamaño, y no como en la forma de pequeñas figuras votivas guardadas en gazofilacios, y que dichos orfebres producían elementos con los más elevados procesos de fundición, amalgama y laminación, cuyos 
Las lagunas de Siecha y Guasca, departamento de Cundinamarca.

Fotografía: Philipp Weigell (2010) Fuente: Obtenida el 15 de octubre de 2018, de

https://es.wikipedia.org/wiki/Archivo:Lagunas_de_Siecha.jpg Licencia CC BY 3.0

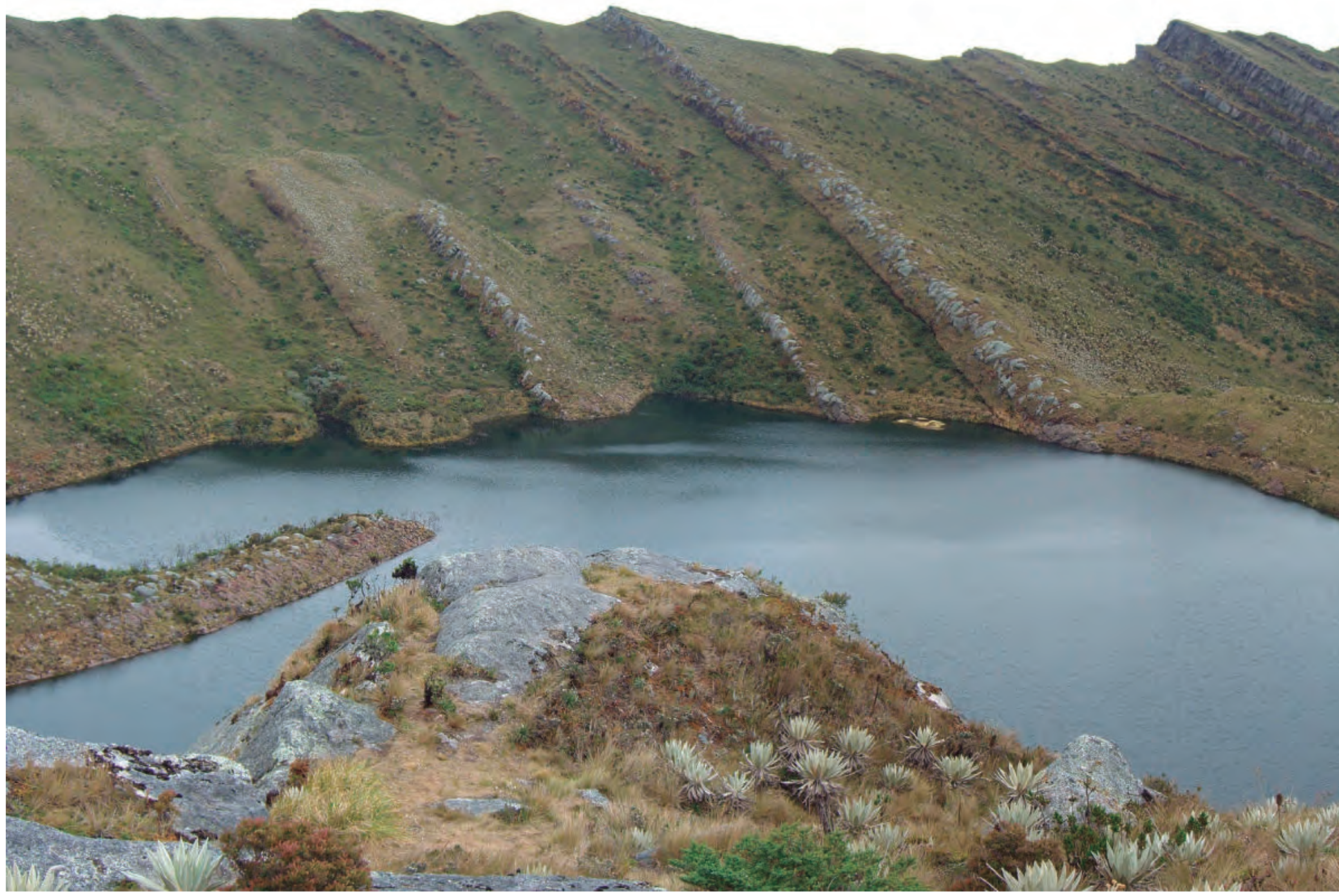




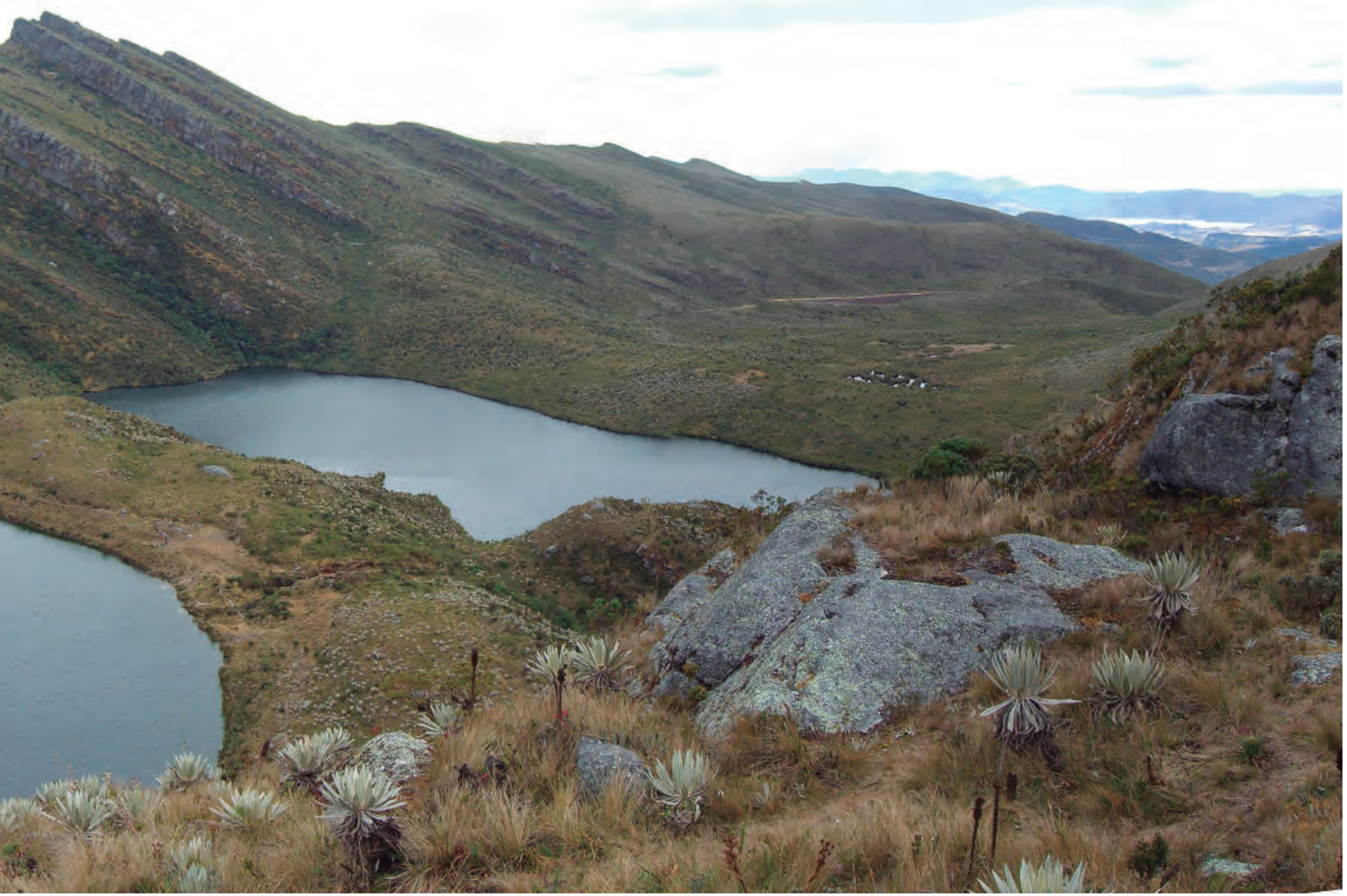


resultados de delgadez y sutileza correspondían a una realización con la más alta tecnología disponible para la época. Además, aseveró que los logros de estos maestros eran el resultado de procesos de repujado efectuados sobre pequeñas matrices en piedra, que se transformaban en figuras de detallado relieve, puesto que eran peritos en los métodos de vaciado, soldadura y bruñido.

Acuña (1942b) sostuvo, además, que el amor por el trabajo dotaba al orfebre de un esmero en el oficio de la filigrana y del proceso de entrelazado, que convertía el oro en el más dócil y sumiso material; que esta forma, toda producción artística realizada en oro por los chibchas, se tornaba en elementos de gran popularidad, puesto que se trataba de un pueblo con una gran sensibilidad artística, de gran espiritualidad, que utilizaba para sus ritos de adoración figuras de pequeños íconos y representaciones de figuras votivas, las cuales se turnaban entre aborígenes creyentes.

La visión de Acuña sobre la cosmogonía chibcha se vio reflejada en el siguiente texto:

El tan complejo ritual funerario de los chibchas, con el más fino y bien labrado oro se servía. En oro macizo de la más alta ley estaba esculpida, de tamaño natural, en su templo de lguaque, la imagen de aquel niño que sacara Bachué, de entre las aguas de la laguna sagrada, el que años más tarde la fecundara e hiciese compañía, por lo cual fue exaltado en el panteón chibcha a la categoría de deidad genitora de la raza. Las mujeres en trance de maternidad a Cuchaviva -el arco iris- en acción propiciatoria ofrézcanle el oro de sus fíbulas, ajorcas y arrancadas. Las representaciones de Bochica, el más popular de sus dioses por haber sido su héroe civilizador, tan sólo en oro eran forjadas, Atha, la rana sagrada, símbolo de la humanidad, y las serpientes acuáticas en que reencarnaran la madre Bachué y el padre Iguaque, caramente los guardaba el pueblo en prolijas representaciones áureas. (Acuña 1942a, 1039)

Fray Pedro Simón ([1626] 1981) relató la siguiente anécdota que le sucedió a un padre doctrinero a propósito de los primeros brotes de sincretismo en el pueblo de Cogua. Comentó que, habiendo convivido con un indio que había dado muestras de ser muy cristiano, este, estando próximo a morir, solicitó a su párroco los buenos oficios para obtener un buen viaje a la muerte. Para tal efecto, el prelado hizo uso de una cruz hecha en palma, que era utilizada durante el Domingo de Ramos, y que estaba en posesión del sobrino del indio; una vez 


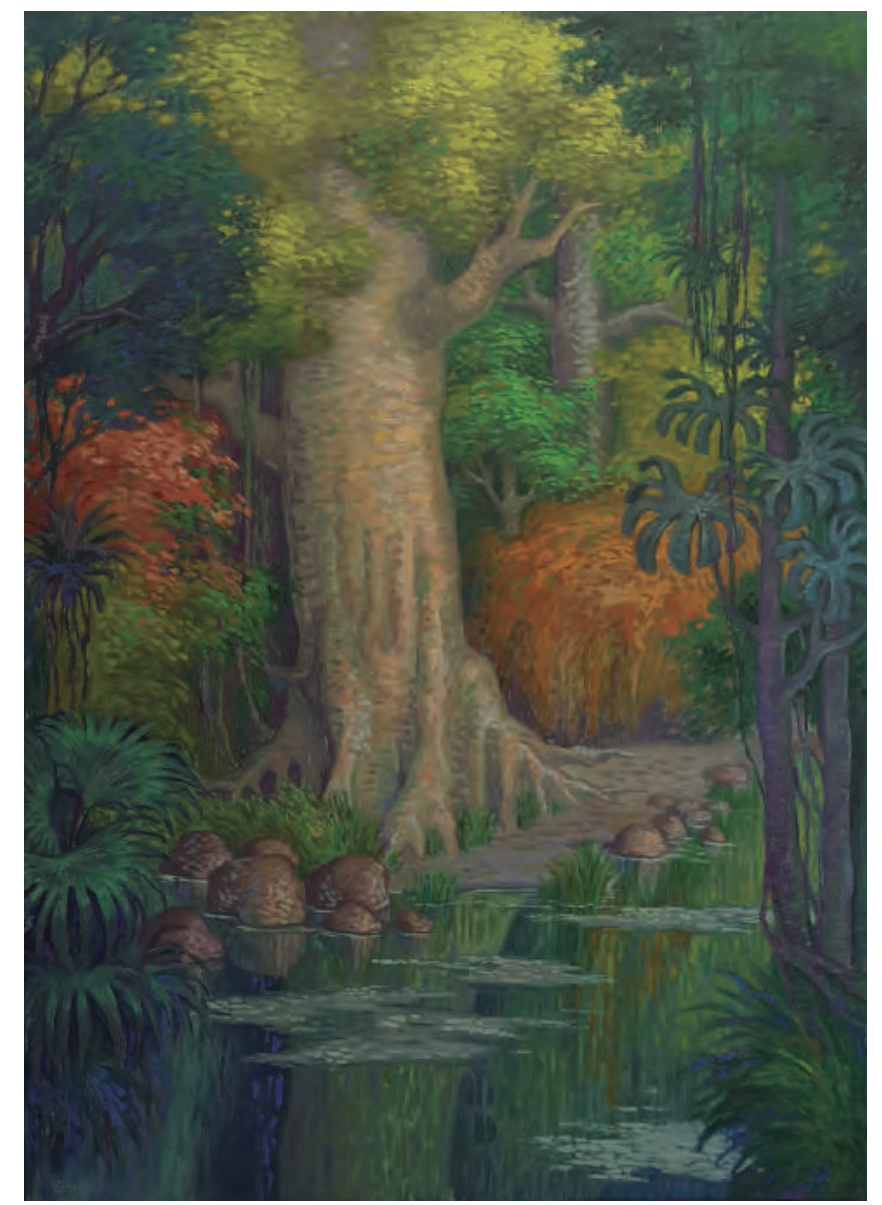

Sin título. Óleo sobre lienzo. Luis Alberto Acuña. (1973) Fuente: Colección privada. Fotografía: Diego Carrizosa.

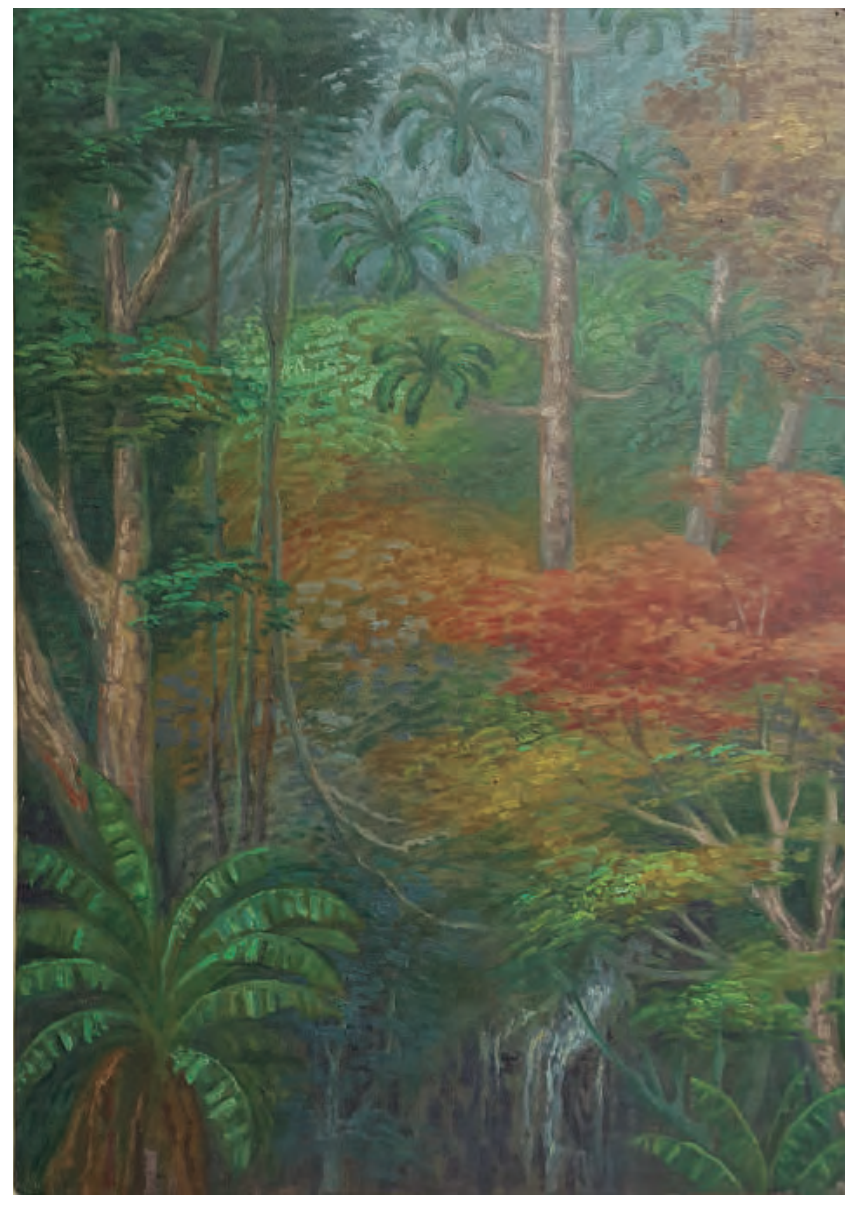

Sin título. Óleo sobre lienzo. Luis Alberto Acuña. (s.f.) Fuente: Colección privada. Fotografía: Diego Carrizosa. 


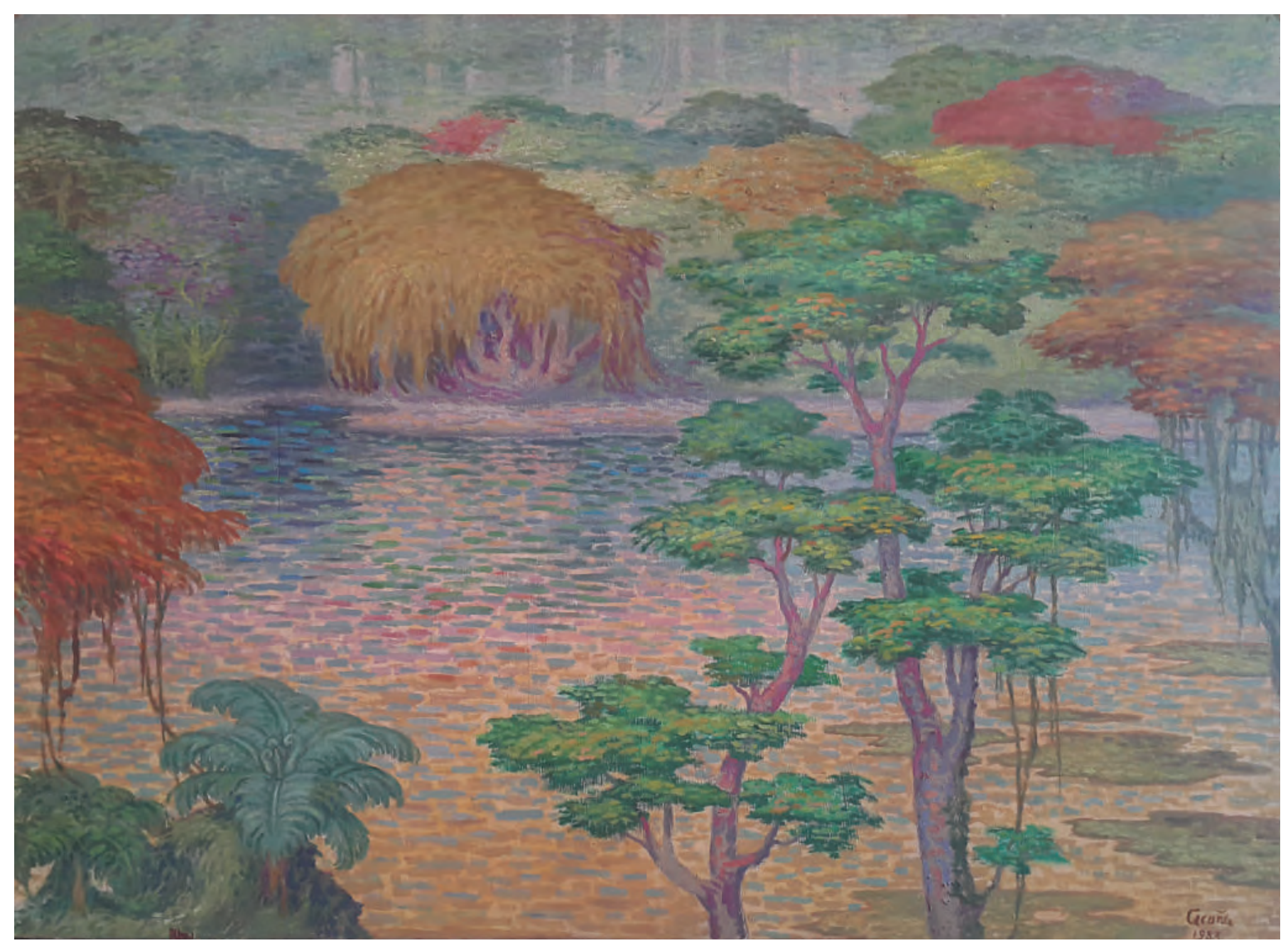

Sin título. Óleo sobre lienzo. Luis Alberto Acuña. (1983) Fuente: Colección privada. Fotografía: Diego Carrizosa. 
inició la ceremonia y mientras movía la cruz de un extremo al otro, cayó de ella la figura de Bochica elaborada en oro. De este testimonio, se deduce que la idea del indio era morir en la adoración de su dios Bochica, y desde luego consintiendo con las exhortaciones cristianas.

Acuña (1965-1986) explicó que, con la llegada de los españoles, las deidades, los mitos y los símbolos chibchas sufrirían el comienzo de su fin, determinando, muy a pesar de esta sociedad, otra ruta por seguir con sus preceptos sobre cristiandad e imponiendo a la fuerza la cultura occidental. Asimismo, señaló que la escultura religiosa española actuó entonces como transmisora del ideario cristiano adaptándose a su nuevo rol y despojando a las deidades americanas de sus mágicos y míticos poderes. Los frailes encargados de realizar el proceso de evangelización en las capillas doctrineras utilizaron de manera efectiva la estatuaria religiosa cristiana como vía de conversión hacia una nueva creencia que dejaron a los indígenas estupefactos y convencidos, gracias a esta efectiva dialéctica. Además, termina su relato con el siguiente pensamiento, que permite al lector interpretar de mejor manera las implicaciones de este acontecimiento:

Pronto la deidades indígenas se van trocando por las del santoral católico y es así como San
Cristóbal suplanta a Chibchacún, divinidad que sustenta la tierra según el mito chibcha; San Agustín, Santo Domingo o San Francisco toman el puesto que hasta ahora ocupara en las mentes indígenas el anciano Bochica, su héroe civilizador; y hasta Huitaca es remplazada por el mismísimo demonio. (27)

Así fue como paulatinamente la cultura chibcha, antigua habitante de lo que es hoy el altiplano cundiboyacense, tuvo que renunciar a sus deidades, y por ende cambiar su imaginería religiosa por otra totalmente ajena a sus creencias ancestrales que dio inicio al proceso de retiro de la cosmogonía chibcha de los saberes de la humanidad, el cual tuvo como consecuencia la destrucción del nivel cultural alcanzado.

Los resultados de las investigaciones publicadas por Acuña, que tienen como fuente los hallazgos publicados por los diferentes investigadores de la cultura chibcha, y que se reflejaron en su visión artística, buscaron evitar el proceso de retraimiento de la visión cosmogónica de esta sociedad y otorgarle su justo lugar en los anales de las expresiones culturales de las sociedades precolombinas. Es en este sentido que deseó preservar para la historia los conocimientos tradicionales desarrollados por esa sociedad, en cuanto a su in- 
terpretación sobre lo místico y su visión de la naturaleza, por medio de la representación plástica de algunos elementos de especial significación de la organización social y religiosa chibcha.

Dentro de la siguiente clasificación se encuentran las figuras que trabajó Acuña conforme a la tendencia bachuísta de temas precolombinos. Deidades: Bachué, Bochica, Chaquén, Chibchacún, Chía, Cuchaviva, Chiminichagua, Huitaca, Iguaque, Nemcatacoa o Fo, Sía y Sua); jerarcas: el cacique, el jeque, el zaque y el zipa); animales con representación mitológica: serpientes y ranas; elementos de ofrenda: aves, esmeraldas, textiles y oro.

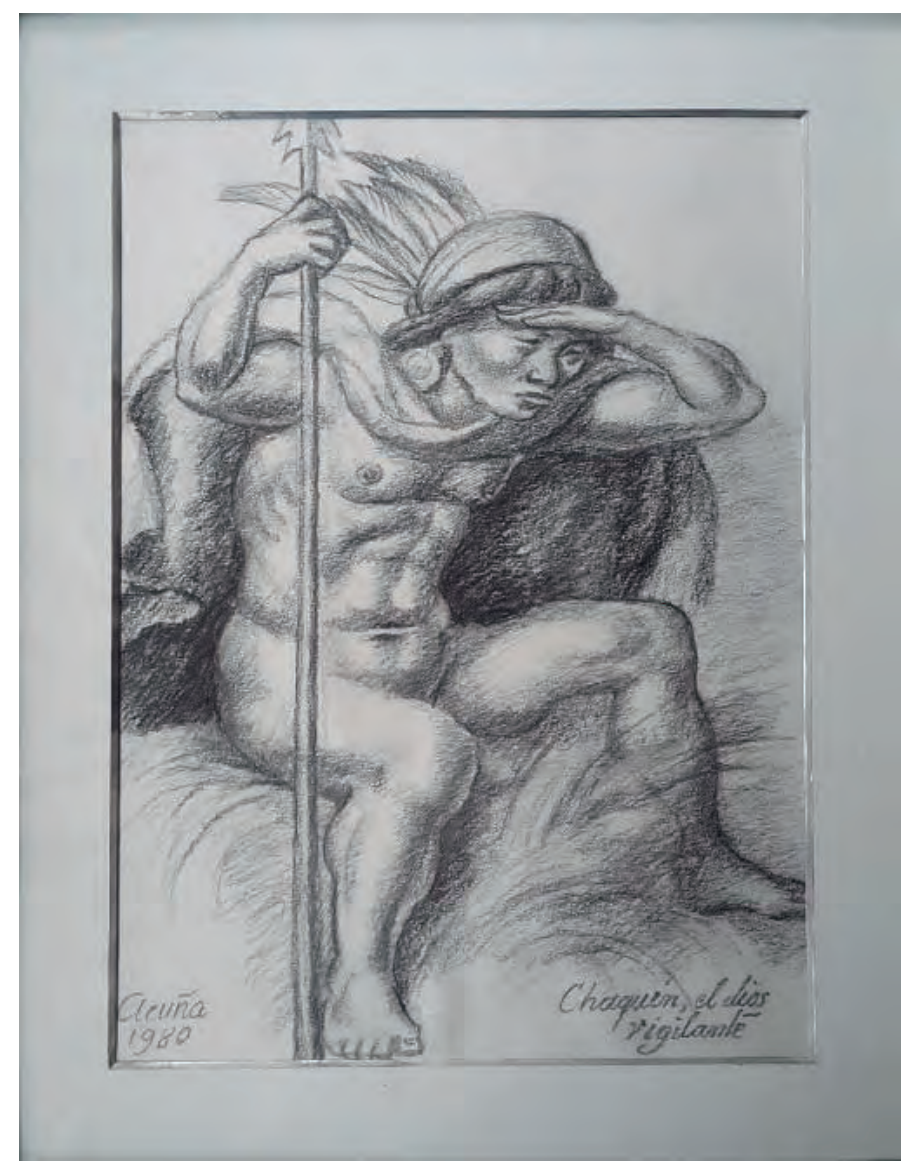

Chaquén. Carboncillo sobre papel. Luis Alberto Acuña. (1980) Fuente: Colección privada. Fotografía: Diego Carrizosa. 


\section{Nociones}

\section{sobre el}

concepto de

expropiación

del universo

simbólico de

una sociedad

prehispánica

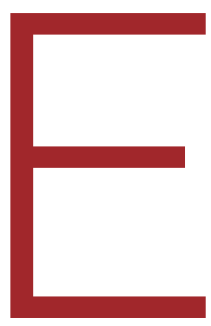

n virtud de lo expresado por Acuña, se considera importante reflexionar, por medio de nociones que giran dentro del pensamiento eurocéntrico, sobre las razones que motivaron la destrucción de los universos simbólicos de las sociedades prehispánicas por parte de los conquistadores españoles.

Aníbal Quijano (2000) expuso que los conquistadores en América encontraron una gran diversidad de poblaciones, cada una con historia, lengua, cultura, identidad y memoria propias, algunas con mayores niveles de desarrollo, principalmente los aztecas y los mayas en Centroamérica, y los chimús, aimaras, incas y chibchas en Suramérica.

Como es conocido, el dogma de la fundamentación de las religiones reside en la lucha entre las fuerzas del bien y del mal, de ahí que el planteamiento europeo radicó en interpretar los dioses prehispánicos como malignos, que inducían al error a quien los adoraba, puesto que no se trataba de dioses buenos sino de entidades malignas que trasladarían al infierno a las ánimas. Señaló, además, Quijano (2000) que tres centurias después todos ellos continuaban siendo identificados bajo una identidad común que sería denominada "indios". Esta nue- 
va tipología que proveía identidad era de características raciales, coloniales y negativa en todos los sentidos. Las consecuencias de lo anterior se traducian en la anulación de la identidad histórica que caracterizaba a cada sociedad como única. De ahí que la nueva identidad racial, colonial e impuesta de manera negativa, significaba su retiro de la historia de la producción cultural global. Desde entonces los "indios" eran considerados pertenecientes a razas inferiores, con capacidad solo de crear culturas igualmente inferiores.

A partir de lo expuesto, es posible deducir que la inclusión de esas diferentes culturas en un mundo dominado por Europa dio como resultado un nuevo patrón de orden mundial, que expropió a las sociedades prehispánicas de sus procesos de producción de conocimiento, destruyó los conocimientos adquiridos y, por ende, su universo simbólico.

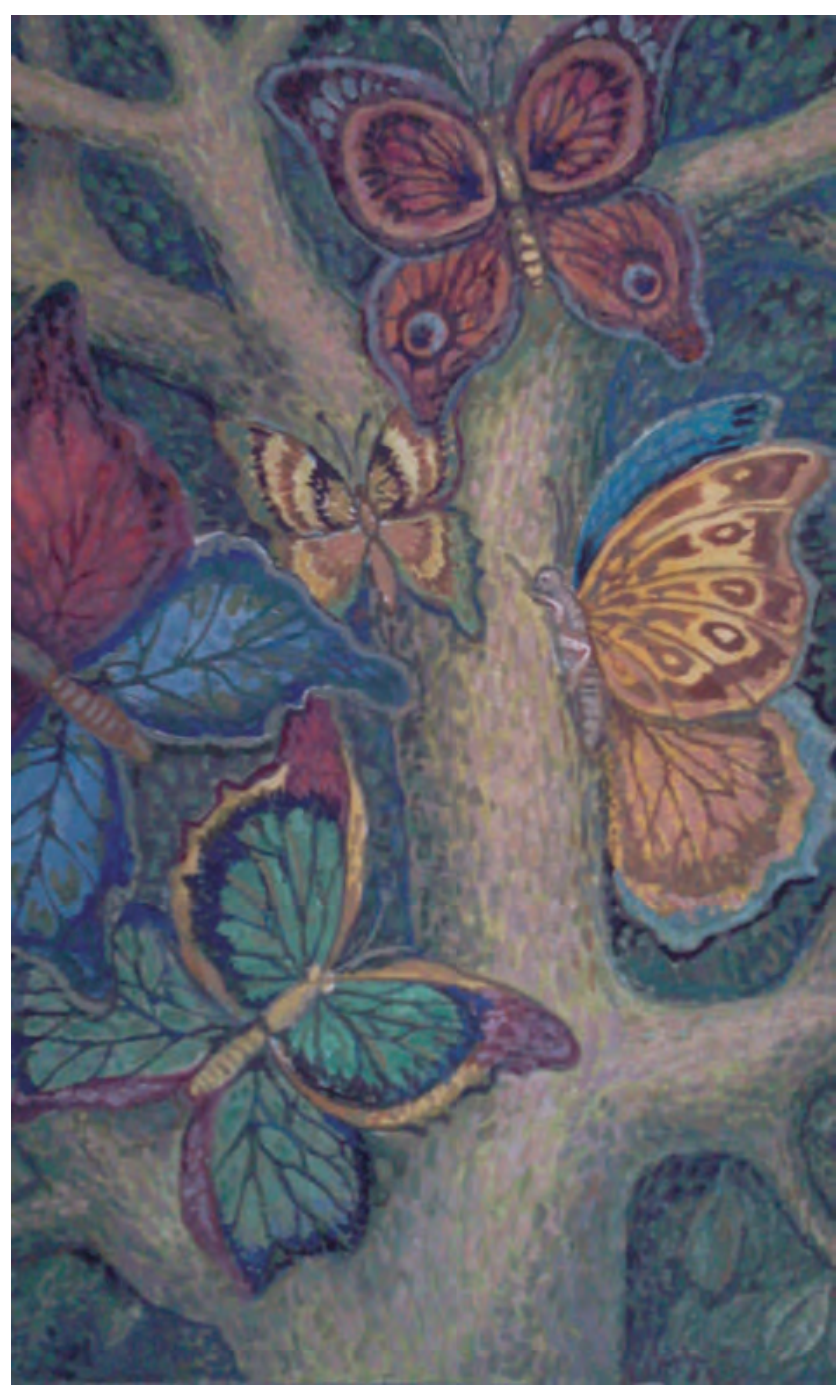

Mariposas. Óleo sobre madera. Luis Alberto Acuña (1988). Fuente: Colección Casa Museo Luis Alberto Acuña, Villa de Leyva, departamento de Boyacá. Fotografía: Diego Carrizosa. 


\section{¿De qué manera}

\section{emergen el arte}

rupestre y las

\section{representaciones}

cosmogónicas

chibchas en

la obra

literaria

y plástica

de Luis

Alberto Acuña? os chibchas le rendían culto a casi todas sus deidades, a excepción de Chiminichagua, el supremo dios creador, a quien, por su importancia, no se lo adoraba de manera directa sino por interpuesta figura, como es el caso de Sua y Chía. Fray Pedro Simón se refirió al tipo de representaciones de las diferentes deidades que podían ser realizadas por los chibchas en el texto Noticias historiales de las conquistas de tierra firme en las Indias Occidentales ([1626] 1953):

Las figuras de estos dioses hechas al modo de cada uno que los adornaba o mandaba hacer y otras que imaginaban, tenían en templos comunes y particulares, pero todos sin ornato ni grandeza, al fin como para quien eran, pues sólo era una casa o bohío muy ordinario lleno de barbacoas y poyos a la redonda, donde están puestas varias figuras de diversos metales y materias, ningunos pintados, porque eran de oro, y éstos usaron más después entraron los españoles, por haberles visto estimarlo en tanto.

Tenían en los templos comunes dos maneras de cepos o gazofilacios, en que metían las ofrendas que se les hacían: la una era 
una figura de hombre hecha de barro, sin pies, toda hueca, abierto todo el casco de la cabe$z a$, por donde echaban las ofrendas, que eran hechas de oro con figuras de varios animales, como culebras, ranas, lagartijas, mosquitos, hormigas, gusanos, leones, tigres, monos, raposas, y toda suerte de aves. Estas sólo las ofrecía el jeque.

Otras [eran] de madera, otras de hilo de algodón, otras de barro blanco, otras de cera. Pero de todas había macho y hembra revueltos en mantas, unas sin cabellos, otras los tenían muy largos, unas con largas colas de dos o tres varas, otras las tenían muy pequeñas; pero todas en rostros y talles de figuras tan abominables que representaban bien a quien estaban dedicadas. (3:378)

Del texto anterior es posible deducir que cada chibcha construía sus propias deidades de acuerdo con sus imaginarios estéticos y cosmogónicos o sus propias necesidades y deseos.

Ningún sacrificio ni ofrenda se podía hacer sino por su mano, particular ni común, porque todavía en las ofrendas comunes y por causas graves, sacrificaban al sol, que, como hemos dicho, era el principal a quien adoraban, no en templos, porque decían era imposible meter tanta majestad entre paredes, sino en altas cumbres a la parte que miraban al oriente, a donde llevaban los jeques, juntándose muchos para esto [...] No todos tenían sus adoraciones en los templos, pues la de muchos las tenían dedicadas en lagunas, arroyos, peñas, cerros y otras partes de particular y singular compostura y disposiciones, no porque tuviesen estas cosas por dioses, sino que por la singularidad que tenían, les parecía ser dignas de mayor veneración o porque pasando por ellas, les había sucedido alguna singular cosa [...] Cuando se iban acabando, mandaba el jeque se hiciese de oro, cobre, hilo o barro la figura que habían de ofrecer, que solía hacer de una águila o serpiente, mono o papagayo o de otras así. (3:384-386)

A partir de lo escrito por fray Pedro Simón, y de acuerdo con Edith Jiménez de Muñoz (1951), quien expuso la razón por la cual es difícil tener hoy en día muestras de piezas completas o segmentos que puedan dar una idea de las formas que pudieron haber tenido esas deidades (deterioro, por el paso del tiempo, de materiales como la madera, el hilo de algodón, la cera y, en algunos casos, el barro), se puede inferir que probablemente existie- 
ron representaciones de deidades chibchas como Chibchacún, Bochica, Huitaca, Cuchaviva, Nemqueteba, Nemcatacoa y Chaquén, entre otras, pero que no se conoce su iconografía, porque no se ha encontrado hasta ahora ninguna imagen que los represente. ¿Cómo lucian entonces estas deidades? ¿Cuáles eran sus formas? Las respuestas a estas preguntas podrían sustentarse con la siguiente noción: los dioses efectivamente sí fueron representados pero en formas simbólicas, puesto que con las aves personificaron al dios sol, con las serpientes a Bachué y con el gato montés significaron al dios Nemcatacoa, principalmente (Jiménez 1951, 189).

De acuerdo con la reflexión anterior, probablemente los conquistadores no comprendieron el significado de las representaciones que, como bien lo mencionó Acuña, eran muy esquemáticas, con énfasis en las formas geométricas. Sin este tipo de interpretación sobre la relación que se presenta entre el contenido representante de una imagen (su forma) y su contenido significante (lo que significa esa forma), es muy probable que en los museos hoy en día no encontrásemos figuras como las aves, las serpientes o el gato montés, entre otras más, por cuanto probablemente los conquistadores o los evangelizadores las hubiesen destruido o mandado destruir.
A continuación, se presenta una serie de reproducciones de arte rupestre y arte prehispánico en la forma de dibujos, fotografías y pintura mural, sobre los cuales se realiza un análisis iconográfico en concordancia con los resultados de las investigaciones de otros pensadores y de Acuña, con el propósito de reflexionar en torno a los aspectos comunes y no comunes, que se pueden encontrar entre las figuras investigadas y reproducidas en los textos y la manera en que ellas se reflejan dentro del ejercicio de la plástica de Acuña.

\section{El arte rupestre}

Miguel Triana, quien fuese miembro numerario de la Academia Colombiana de Historia desde 1924, hasta el año de su muerte acaecida en 1931, puede ser considerado como el pionero de la investigación en el país sobre lo que hoy se conoce como arte rupestre. Triana, como resultado de sus investigaciones, atribuyó la autoría de los pictogramas a los chibchas y consideró a los panches como los autores de los petroglifos, en razón de que durante sus exploraciones solo encontró petroglifos en territorio panche y piedras pintadas en tinta roja en territorio chibcha, además porque "sospechó" que los panches "tenían un desarrollo mental superior al de los chibchas y que consiguientemente, poseían un acopio de ideas 
de carácter científico más abundante que el de éstos" (1922, 175). Esta aseveración, que concuerda con el saber específico existente en Colombia a inicios de la década de 1920 sobre este tipo de temas, se da en un momento histórico en el que disciplinas como la investigación arqueológica no tenían mucho desarrollo en Colombia. Las fuentes utilizadas por Triana fueron el padre jesuita José de Acosta, Vicente Restrepo, fray Pedro Simón y Liborio Zerda, escritores respetados que publicaron en diferentes periodos históricos relatos sobre la cosmogonía del pueblo chibcha. Tanto en La civilización chibcha (1922) como El jeroglífico muisca (1924) Triana se refirió al contenido grabado y dibujado en las piedras que sirven de soporte al arte rupestre como jeroglíficos. Asimismo, documentó la localización geográfica del arte rupestre, reprodujo los diseños simbólicos encontrados en los petroglifos y la escritura planteada por medio de imágenes de los pictogramas, habló de su técnica de elaboración, y explicó las razones de su conservación a lo largo del tiempo. El resultado de estas investigaciones hoy puede ser considerado como una base importante de información, para que, a partir de esos contenidos, se profundice en el estudio de arte rupestre existente en el altiplano cundiboyacense. Acuña interpretó el arte rupestre de la siguiente manera:
Las pinturas sobre piedra que abundan en algunos lugares de Colombia [...] son de una morfología tan curiosa y de un abstracto tan sugerente, que por estas muy principales circunstancias, y por las no menos importantes de estar trazadas con tintas rojas indelebles, en lugares especialmente visibles, en una orientación determinada, con una repetición insistente figuras o caracteres (aún en lugares situados a muy considerable distancia) y con tal semejanza unos de otros que parecen trazados todos por la misma mano, nos atrevemos a pensar que tales pinturas no son otra cosa que signos escriptorios. Pero es lo cierto que estos productos de la cultura chibcha (algunos juzgan como pertenecientes a la cultura caquesia o prechibcha), tienen un muy diferente valor si se los juzga como signos escriptorios, o como mero y vulgar pasatiempo según la versión de Restrepo ([1895] 1972). (Acuña 1942a, 50-54)

Como se puede deducir del texto anterior, Acuña denominó el arte rupestre como signos escriptorios. Una vez revisada la palabra escriptorio en el Diccionario de la lengua española se encontró que no existe. Se presume, entonces, que Acuña, para identificar el arte rupestre, pudo haber utilizado un 


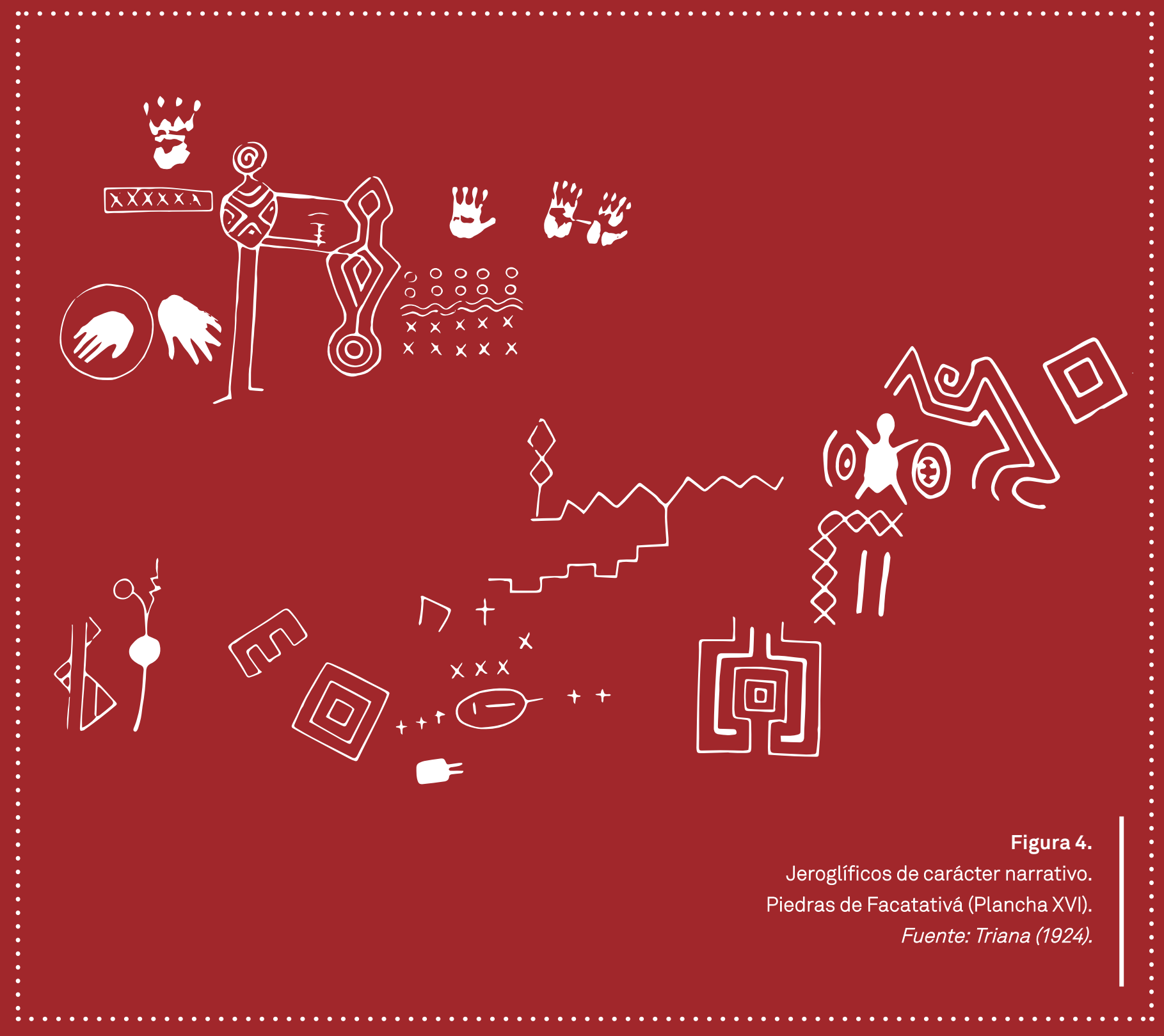


De acuerdo con lo expuesto, se puede deducir que Acuña tenía dudas sobre si estos signos escriptorios (pictogramas) pertenecían o no a la cultura chibcha, por cuanto habla de una cultura caquesia o prechibcha, como sus posibles autores. Las inquietudes que planteaba Acuña pueden responder al conocimiento existente en el país sobre la sociedad que pudo haber realizado el arte rupestre en lo que hoy se conoce como el altiplano cundiboyacense, puesto que en ese determinado periodo histórico no existían las técnicas modernas de investigación que hoy en día se utilizan. Martínez y Botiva (2007) identificaron como arte rupestre las pinturas realizadas sobre las rocas (pictogramas) y los grabados elaborados sobre elllas (petroglifos).

Los diferentes términos: jeroglíficos, signos escriptorios y arte rupestre (pictogramas y petroglifos), que se refieren a un mismo tipo de representación, son utilizados dentro de este libro de acuerdo con el vocablo utilizado por los autores consultados. Respecto de la posible atribución a la cultura chibcha como autora de los pictogramas o petroglifos que se han encontrado, Martínez y Botiva (2007) sostuvieron que, en lo que fue el territorio chibcha, todavía no es posible determinar a qué grupo poblacional se puede adjudicar su creación. Sin embargo, se sabe que pueden datar desde 16500 años, hasta algunos años después del encuentro entre los dos mundos, un término demasiado amplio. Si se remite a los cronistas, de acuerdo con lo citado por Martínez Celis (2008), el naturalista español Bernardo Vargas Machuca (1951), se puede saber que los chibchas negaron ser autores de estas manifestaciones artísticas rupestres, y que atribuían su autoría a ancestros lejanos, por lo que se considera relevante señalar a continuación la manera en que el cronista Vargas registró el hecho en los Apologías y discursos de las conquistas occidentales:

Como a dos leguas o menos de la ciudad Vélez está un río y en él está una peña. Y en ella, esculpir labrada, una cruz, y yo la he visto; queriendo el dicho general (Jiménez de Quesada), saber este secreto de ella, maravillándose mucho de hallarla, le fue hecha relación por indios muy viejos, que de ello más que otros tenía noticias de sus padres y antepasados, que de mano en mano debía venir de más de mil quinientos años, conforme a la cuenta quedaban por lunas, como es si dijésemos meses. (citado por Pérez de Barradas 1951, 326) 


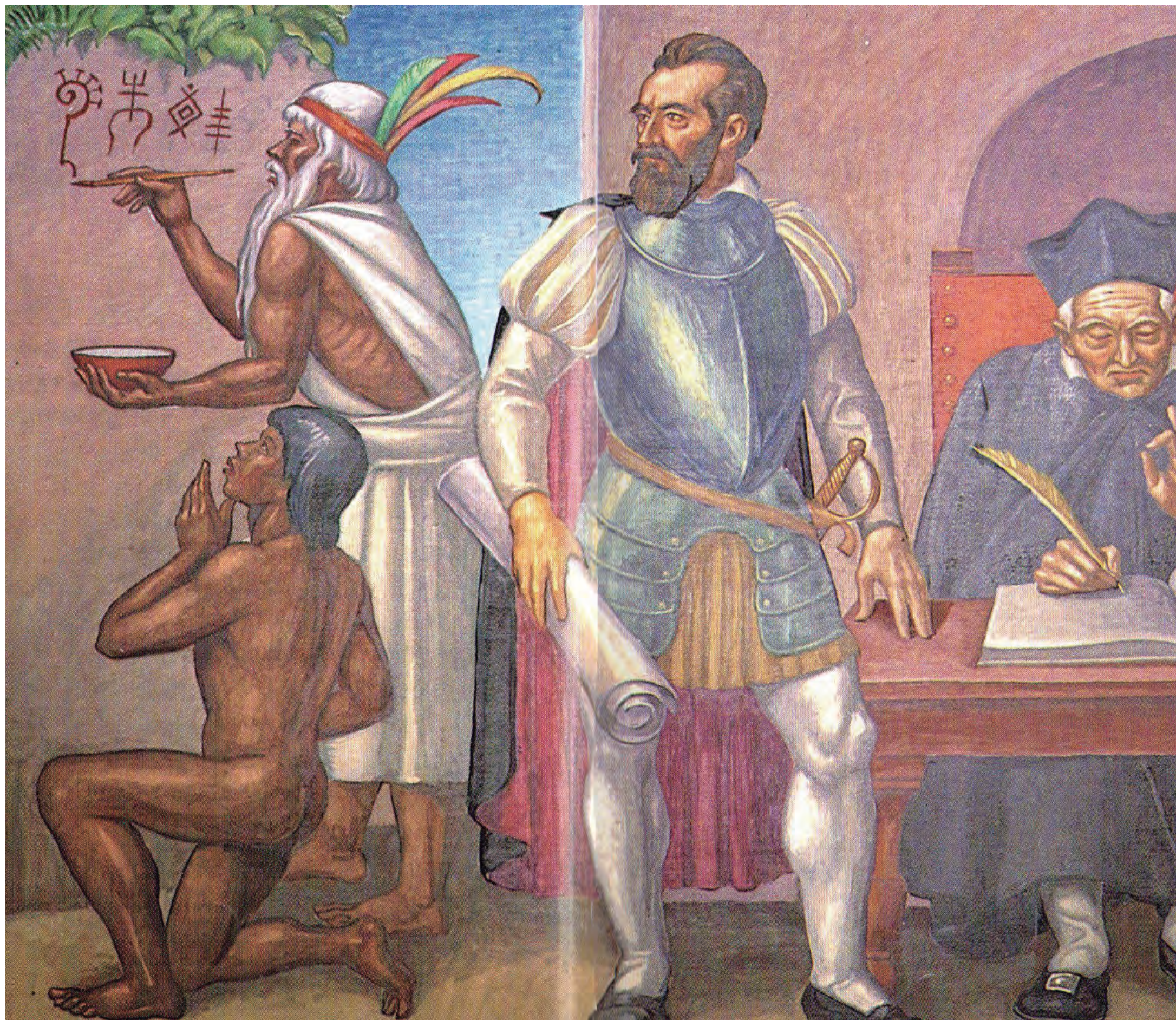




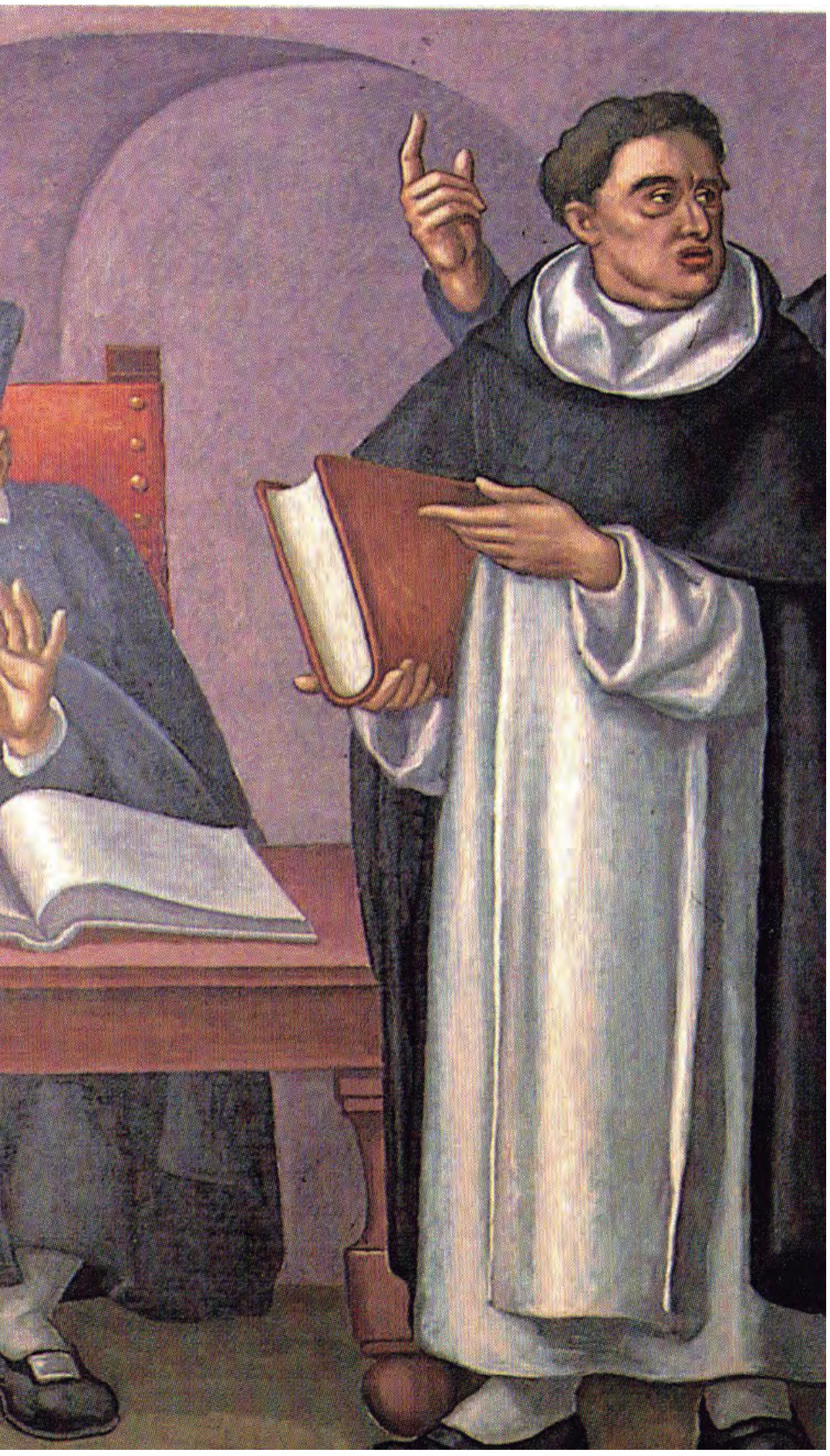

Figura 5.

Óleo Bochica pintando en las rocas y el conquistador Gonzalo Jiménez de Quesada. (s.f.) Luis Alberto Acuña.

Fuente: Obtenida el 21 de septiembre de 2013, de http://www.rupestreweb.info/tmyc.html Fotografía obtenida por P. Rouillard, tomada del libroXiménez de Quesada el caballero de El Dorado. Lucena, Manuel, 1981. 
Figura 6.

Detalle de signo escriptorio,

dibujo sobre papel.

Fuente: Acuña (1942).

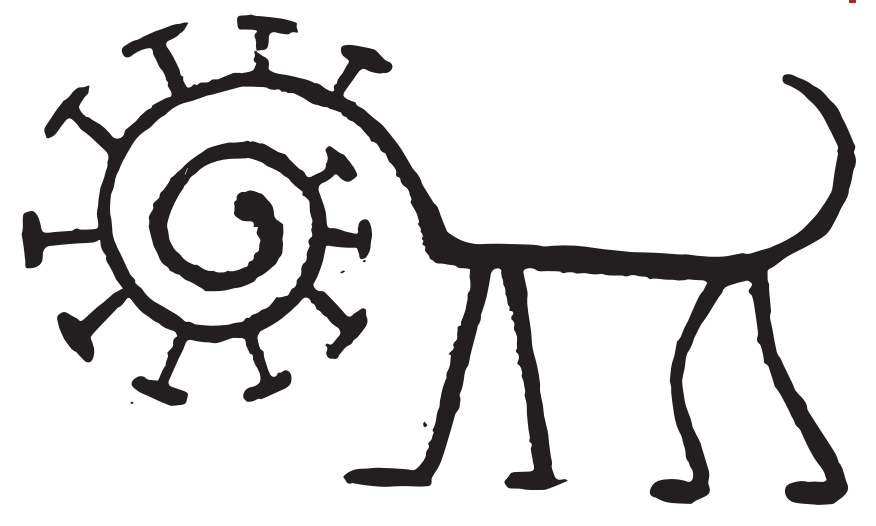

Figura 7.

Signos escriptorios realizados por Luis

Alberto Acuña. Dibujo sobre papel.

Fuente: Acuña (1942).

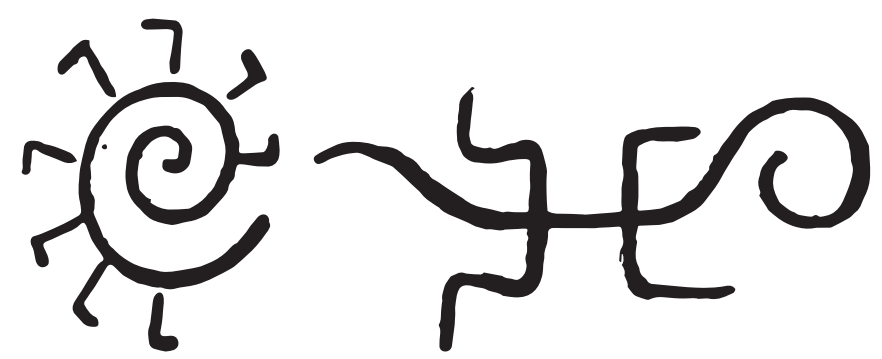

La lectura sobre el contenido de la imagen que se observa en la figura 5 posiblemente hace referencia a una interpretación fantástica que hace Acuña sobre el mito de Bochica, que, en su rol de maestro, pudo haber pintado muchísimos años atrás los signos escriptorios o pictogramas (figura 6), con el objetivo de transmitir alguna enseñanza a la sociedad chibcha. La mirada que posa de Jiménez de Quesada sobre Bochica posiblemente busca comprender el significado de los pictogramas.

En lo que atañe a los dibujos realizados por Acuña sobre las representaciones de arte rupestre, las cuales fueron publicadas en el libro El arte de los indios colombianos (Ensayo crítico e histórico) de 1942 (figura 7), se puede evidenciar que Acuña utilizó las imágenes que obtuvo como resultado de sus indagaciones en su plástica. Como es el caso de la figura 7, en la cual se encuentra una escena que, según la mitología
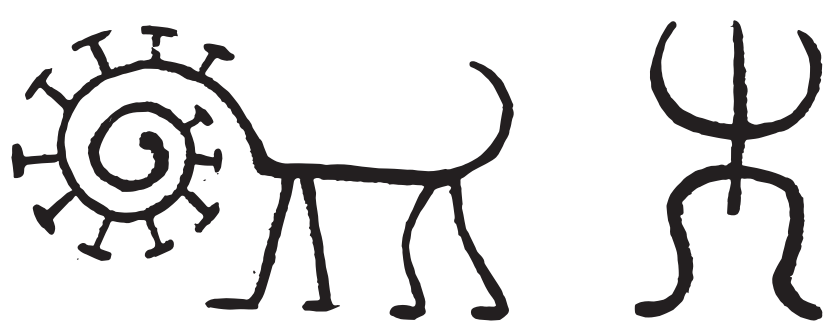
chibcha, y los relatos de los cronistas, no tuvo lugar. Acuña, probablemente, hace uso de una licencia creativa para crear una puesta en escena, que posiblemente él hubiese querido que sucediera. Si se indaga sobre las motivaciones por las que se realizó arte rupestre en lo que hoy es Colombia, por cuanto no solo se encuentra en la región habitada por los chibchas, Martínez y Botiva (2007) sostuvieron varias hipótesis: que se trató de instancias de pasatiempo o fantasía realizadas por parte de sociedades de poca evolución, que pueden ser el resultado de intenciones de expresividad simbólica o manifestaciones comunicativas o que fueron prácticas rituales efectuadas por sociedades complejas. En razón de que los grupos humanos que las realizaron ya no existen, es muy difícil tener conocimiento acerca de tal intencionalidad. Sin embargo, hoy en día, los lugares donde se encuentra arte rupestre son utilizados por comunidades indígenas y de campesinos como espacios sagrados o con connotaciones mágicas. Esta nueva manera de reinterpretar los sitios donde se encuentra el arte rupestre, por parte de los grupos poblacionales mencionados, da a conocer nuevas formas de pensar y de reflexionar sobre la inclusión de manifestaciones artísticas del pasado, en el mundo de hoy.

Una vez se han sustentado las anteriores teorías de acuerdo con Martínez y Botiva (2007), es posible observar de igual manera que se encuentran varias similitudes de tipo iconográfico entre ciertos motivos de arte rupestre encontrados en el altiplano cundiboyacense - lugar de existencia de los chibchas - y algunas manifestaciones artísticas atribuidas a artistas pertenecientes a la civilización chibcha que habitaron entre 600 y 1600 d. C.

\section{El arte rupestre: "el animal encorvado"}

Como se puede notar en la figura $\mathbf{8 a}$, se encuentran varias versiones de un animal encorvado, diseño que pertenece al arte rupestre, el cual, según Martínez y Botiva (2007), es muy común encontrarlo en representaciones de arte prehispánico chibcha, como elementos textiles, piezas de orfebrería, vasijas y copas. Tal es el caso de la vasija muisca-guane (figura $\mathbf{8 b}$ ), en cuyos diseños centrales se puede observar la cabeza del animal encorvado, así como en la figura $\mathbf{8 c}$, es posible detallar el lomo en forma de ángulo del animal encorvado, con la cola enroscada. "La correspondencia entre estos diseños podrá estar indicando que todos estos objetos fueron realizados por un mismo grupo humano, o que se trata de una misma tradición cultural" (Martínez y Botiva 2007, 45). 

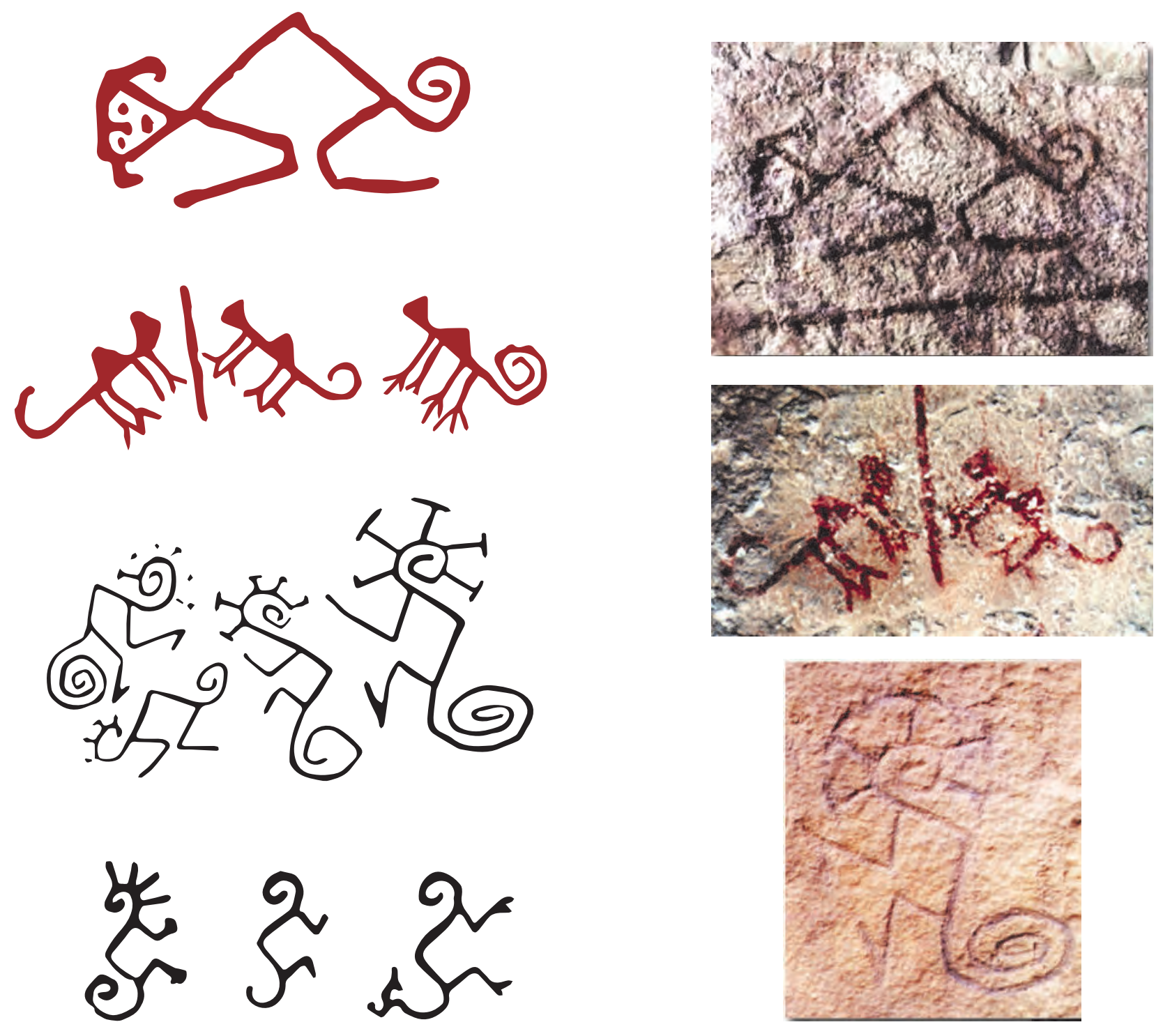

Figura 8a. Tabla de pictogramas y petroglifos rupestres. Fuente: Martínez y Botiva Introducción al arte rupestre (2007). Obtenida el 21 de septiembre de 2013, de http://www.rupestreweb.info/introduccion.html. 


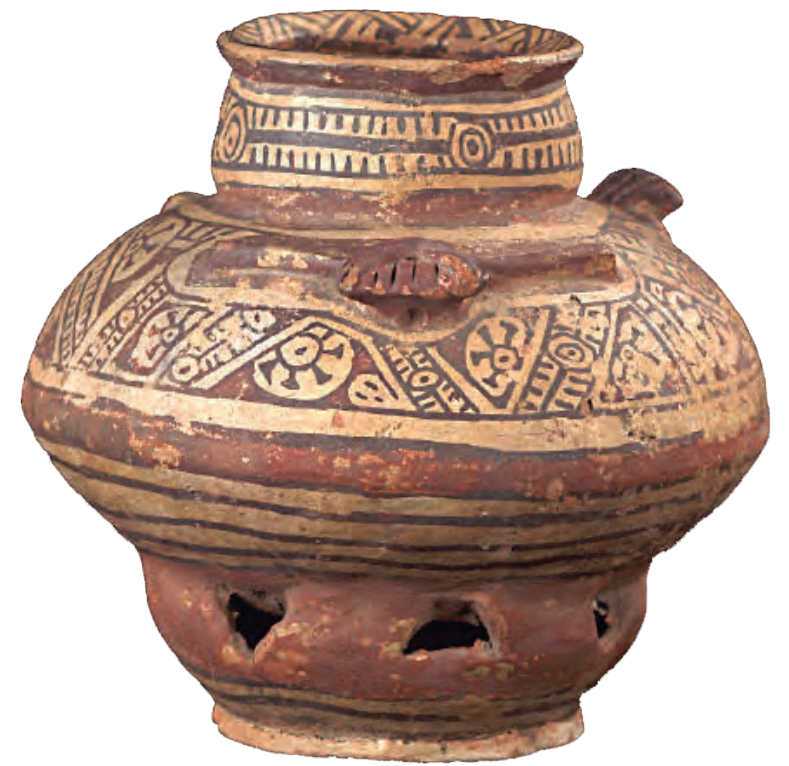

Figura 8b.

Vasija, alfarería muisca-guane, cordillera oriental. Fotografía: Clark Manuel Rodríguez, Museo del Oro del Banco de la República. Banco de la República - Colección Museo del Oro-, titular de los derechos de autor. Ref: C00442.

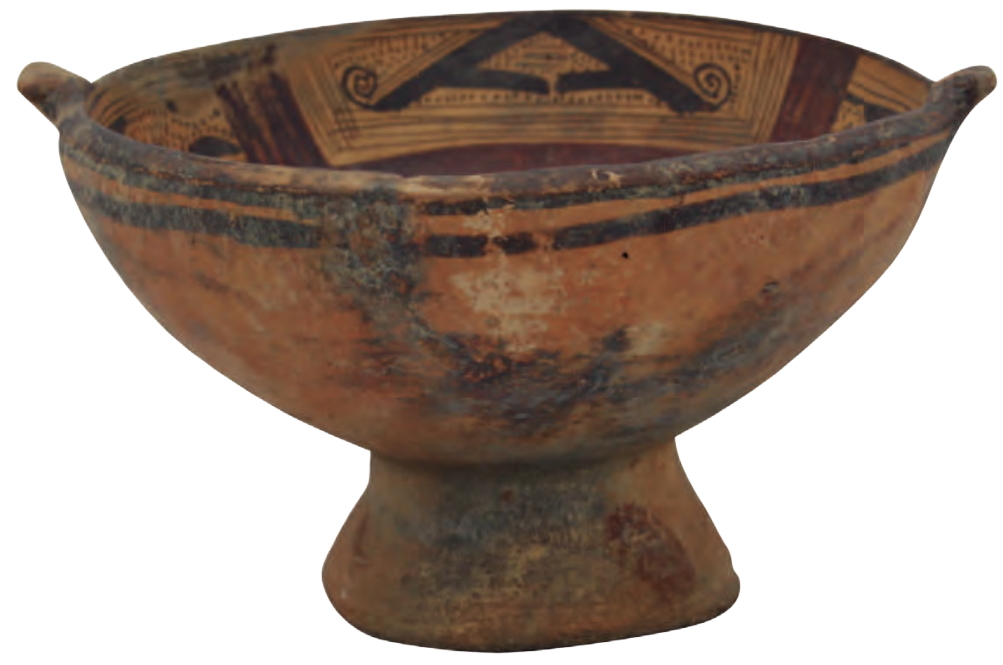

Figura 8c.

Copa, alfarería muisca. Pieza de la colección en tenencia del Museo Arqueológico MUSA. Fotografía: Roberto García Poveda- Museo MUSA. Ref. M-09865. 


\section{Figura 9.}

Petroglifo encontrado en Gámeza, departamento de Boyacá. Fuente:

Martínez y Botiva Introducción al arte

rupestre (2007). Obtenida el 21 de septiembre de 2013, de http://www.rupestreweb.info/introduccion.html

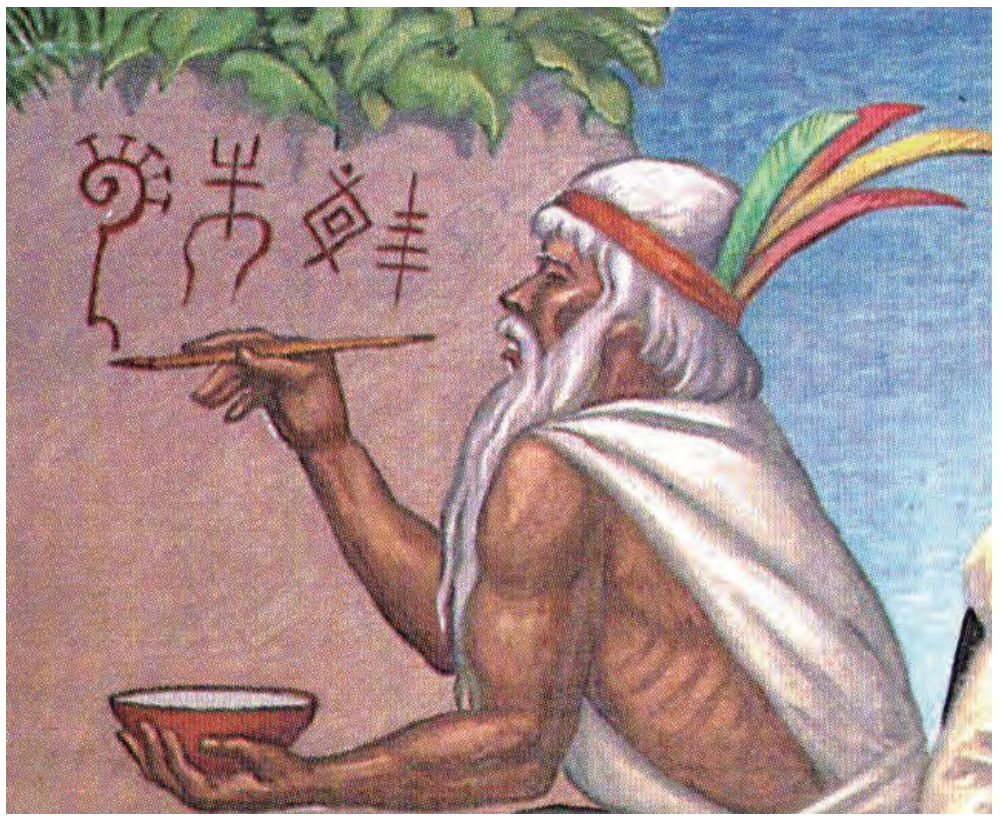

Figura 11.

Detalle del fragmento del óleo Bochica pintando en las rocas y el conquistador Gonzalo Jiménez de Quesada (s.f.). Obtenida el 21 de Septiembre de 2013, de http://www.rupestreweb.info/tmyc.html Fotografía obtenida por P. Rouillard, tomada del libro Ximénez de Quesada el caballero de El Dorado. Lucena, Manuel, 1981.

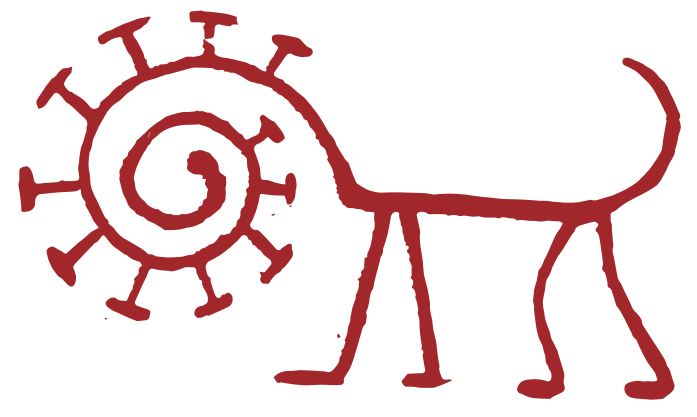

Figura 10.

Detalle de dibujo de signo escriptorio, realizado por Luis A. Acuña para el libro El arte de los indios colombianos (Ensayo crítico e histórico) de 1942. 
En las figuras 10 y $\mathbf{1 1}$, se puede observar en detalle la imagen del animal encorvado de Acuña, en la técnica de dibujo y óleo, respectivamente. La realización de Acuña, que se encuentra en la figura 10 y en parte en la figura 11, por cuanto el signo escriptorio se encuentra en proceso de pintura, presenta algunas similitudes con lo representado en la figura rupestre, como es el caso de la cabeza formada mediante un círculo de espiral creciente, la cual se encuentra acompañada por varios elementos en forma de T. Sin embargo, la dirección de la espiral creciente que comprende la cabeza de la figura 9, gira hacia la derecha, en contraste con la dirección de la cabeza de las figuras 10 y $\mathbf{1 1}$, que gira hacia el lado izquierdo. Además, la figura 11 no cuenta con una angulación sobre su lomo, ni con una larga cola enroscada, pero se encuentra apoyada sobre las cuatro extremidades, en contraste a como se presenta la imagen en el petroglifo de la figura $\mathbf{1 0}$, con solo dos patas, y apoyada sobre las dos extremidades.

Es posible que Acuña se haya inspirado en el petroglifo encontrado en Gámeza (Boyacá), que se observa en la figura 9, para realizar el signo escriptorio que emerge en la figura $\mathbf{1 0}$, así como en la obra en que Jiménez de Quesada observa a Bochica pintar sobre una pared la imagen del animal encovado (figura 11).

Como se señaló, a partir de este encuentro fantástico, se puede deducir que Acuña, mediante una licencia creativa, agrupó dos periodos históricos diferentes, que correspondieron al tiempo en el que se realizó el arte rupestre, con la presencia de Jiménez de Quesada en el territorio chibcha durante la Conquista, situación que conjugó con el mito chibcha que corresponde a la persona del dios civilizador Bochica.

Según Martínez y Botiva (2007), esta imagen del animal encorvado se refiere a la apropiación de la imagen del mono con cola, cuyo culto se dio en una asentamiento chibcha, en la frontera de Tenusucá, el cual se conoce como resguardo de Bojacá, que está situado en las proximidades de la laguna Pedro Palo, lugar en el que el zipa descansaba. En el centro de este resguardo, existía una piedra con la figura de un mono con cola entorchada, cuya imagen no estaba representada en la forma de pictograma, sino en la manera de petroglifo.

\section{El arte rupestre: "el animal encorvado" emerge en el diseño textil chibcha}

Acuña (1942a) explicó que los chibchas decoraban con pincel las mantas, con lo cual demostraban gran habilidad en el oficio. Sostuvo, además, 
Figura 12.

Dibujo de petroglifo (arte rupestre), encontrado en Gámeza, Boyacá. Fuente: Martínez y Botiva, Introducción al arte rupestre (2007). Obtenida el 21 de septiembre de 2013, de http://www.rupes-

treweb.info/introduccion.html

Figura 13.

Dibujo de Acuña en el que se observa un diseño ornamental chibcha, encontrado en una manta.

Fuente: Acuña (1942).

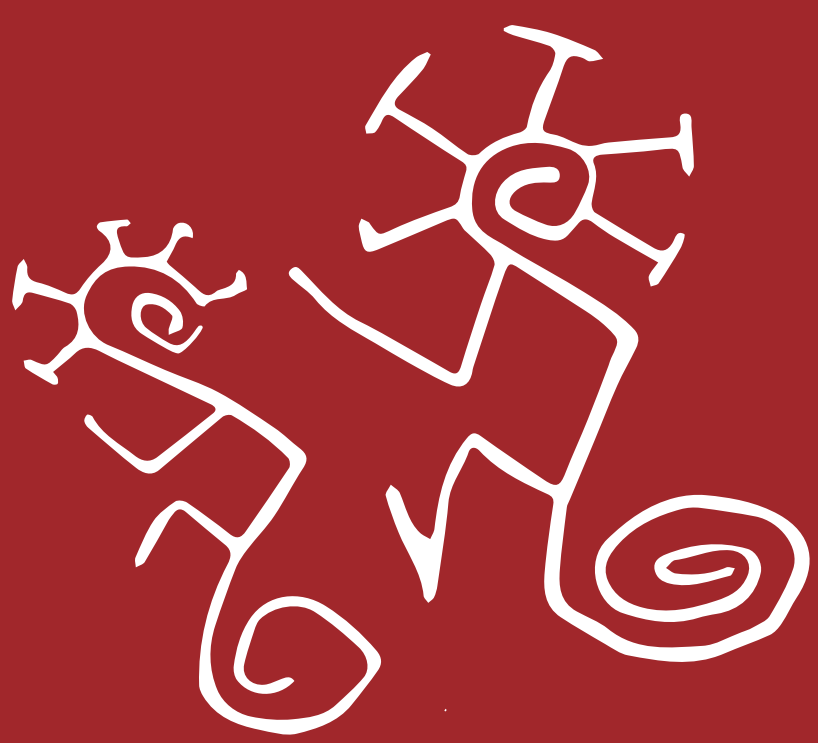

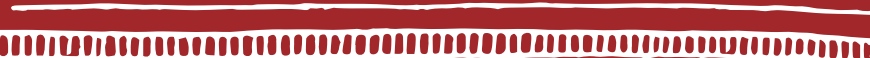
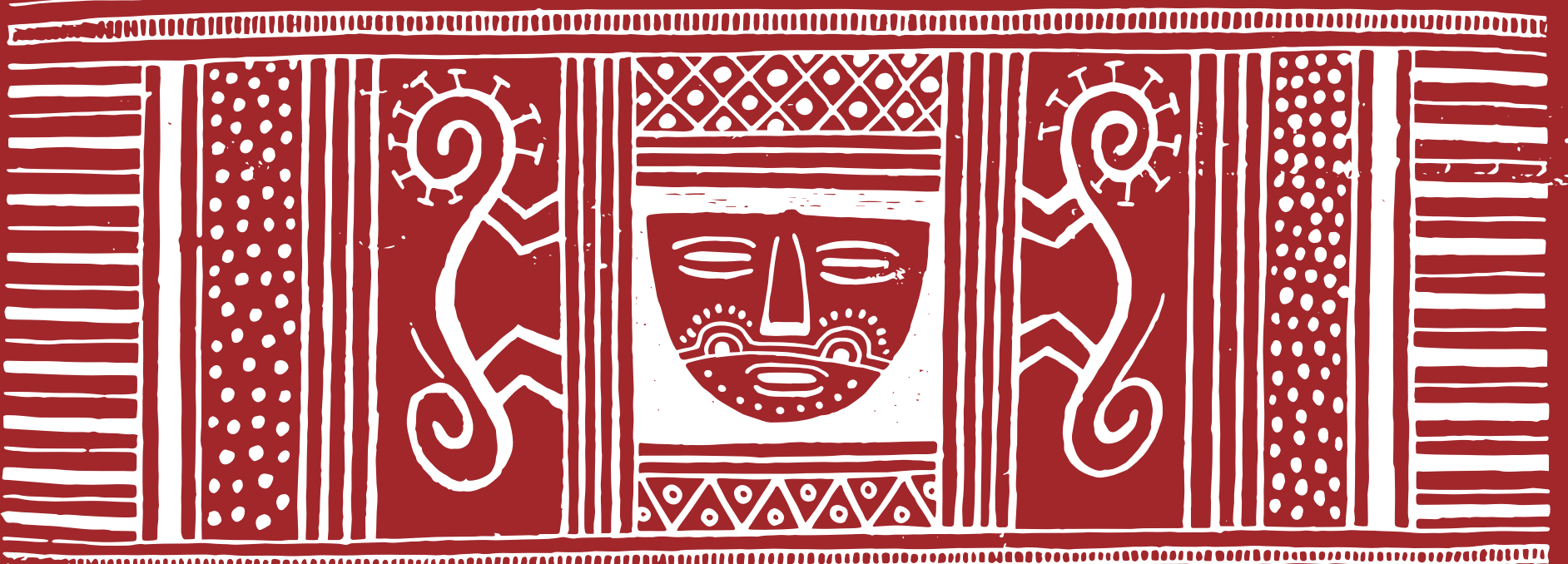

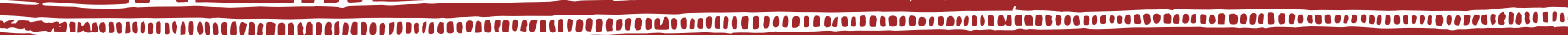

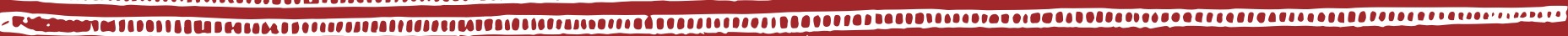




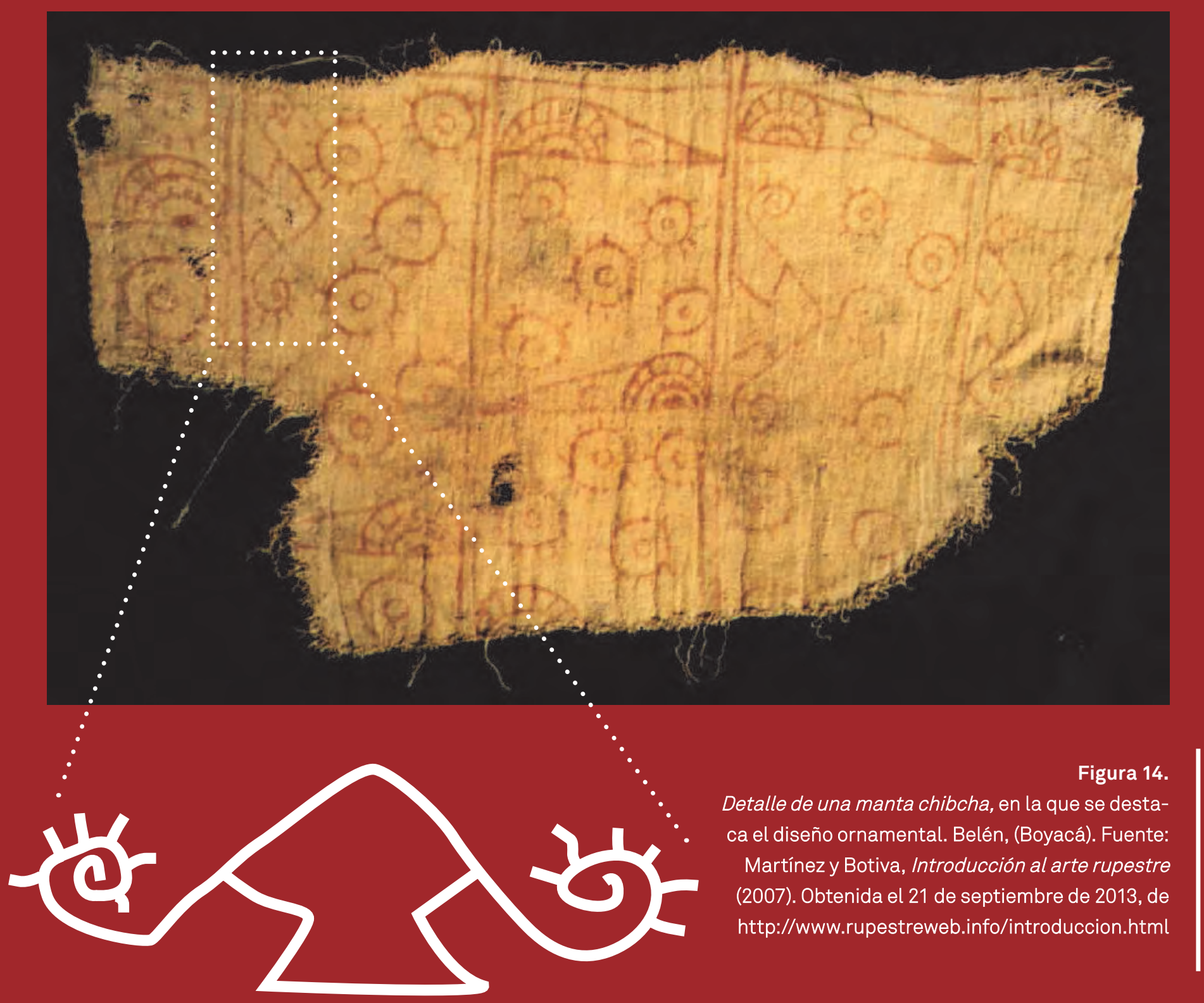


que es muy difícil encontrar muestras de arte textil chibcha, por cuanto estas prendas y los motivos pintados en ellas se deterioraban debido a la humedad y al paso del tiempo. En la figura 12, se encuentra un dibujo de un petroglifo del animal encorvado, encontrado en Gámeza (Boyacá) (Martínez y Botiva 2007). Este dibujo se reproduce con el propósito de resaltar elementos de diseño concordantes con algunas piezas de tejido de la cultura chibcha, tales como el ejemplo de tejido de la

figura 13, reseñado por Acuña (1942), y con la pieza de tejido chibcha (figura 14), encontrada en Belén (Boyacá). En los tres diseños, se pueden observar elementos afines, como la cabeza que comprende varios elementos en forma de $\mathrm{T}$.

Otros elementos comunes comprenden lo siguiente: en la figura 13, se encuentran dos representaciones del animal encorvado, una a la izquierda del diseño y otra a la derecha. La cabeza del animal encorvado, que se encuentra a la izquierda en la figura 13, gira en la misma dirección que la cabeza del animal encorvado, que se observa en la figura 14.

La cabeza del animal encorvado, que se encuentra a la derecha en la figura 13, gira en la misma dirección que la cabeza del animal encorvado que se observa en la figura 12. Respecto del lomo del animal, tanto en la figura 12 como en la figura 14, se observa en forma de ángulo, mientras que en la figura 13 se detalla el lomo en forma de curva. Entre los elementos discordantes, se encuentra el número de patas, dos en la figura 12, cuatro en las dos representaciones que se detallan en la figura 13 y dos en

\section{la figura 14.}

En virtud de las coincidencias que se presentan entre estos aspectos, y como han afirmado Martínez y Botiva (2007), las investigaciones arqueológicas han dado a conocer evidencias de poblamiento humano en lo que hoy es Colombia desde hace 16.500 años. Los arqueólogos han determinado periodos en los cuales emergieron, se desarrollaron y adaptaron al entorno especies vegetales, grupos de cazadores y recolectores, sociedades de agroalfareros, como el periodo formativo temprano conocido como Herrera o prechibcha, hasta el establecimiento de sociedades complejas, como a las que pertenecieron los grupos humanos de la cultura chibcha. A partir de los saberes obtenidos sobre la presencia humana en lo que hoy es el departamento de Cundinamarca, no ha sido posible para los expertos establecer relaciones entre las manifestaciones rupestres con culturas como la chibcha-guane. Sin embargo, es posible afirmar que el conocimiento sobre el arte rupestre data desde el siglo XVI, y que este tipo de arte fue realizado por sociedades que poblaron nuestro territorio antes 
de la Conquista española. De acuerdo con lo expuesto, se puede afirmar que las representaciones rupestres emergieron a causa de contextos rituales y cósmicos, elementos que proveyeron instancias para la creación de un arte con características de magia. Así es como esta imaginería estaría basada en creencias sobrenaturales, en universos no completamente humanos, así como en relaciones cósmicas.

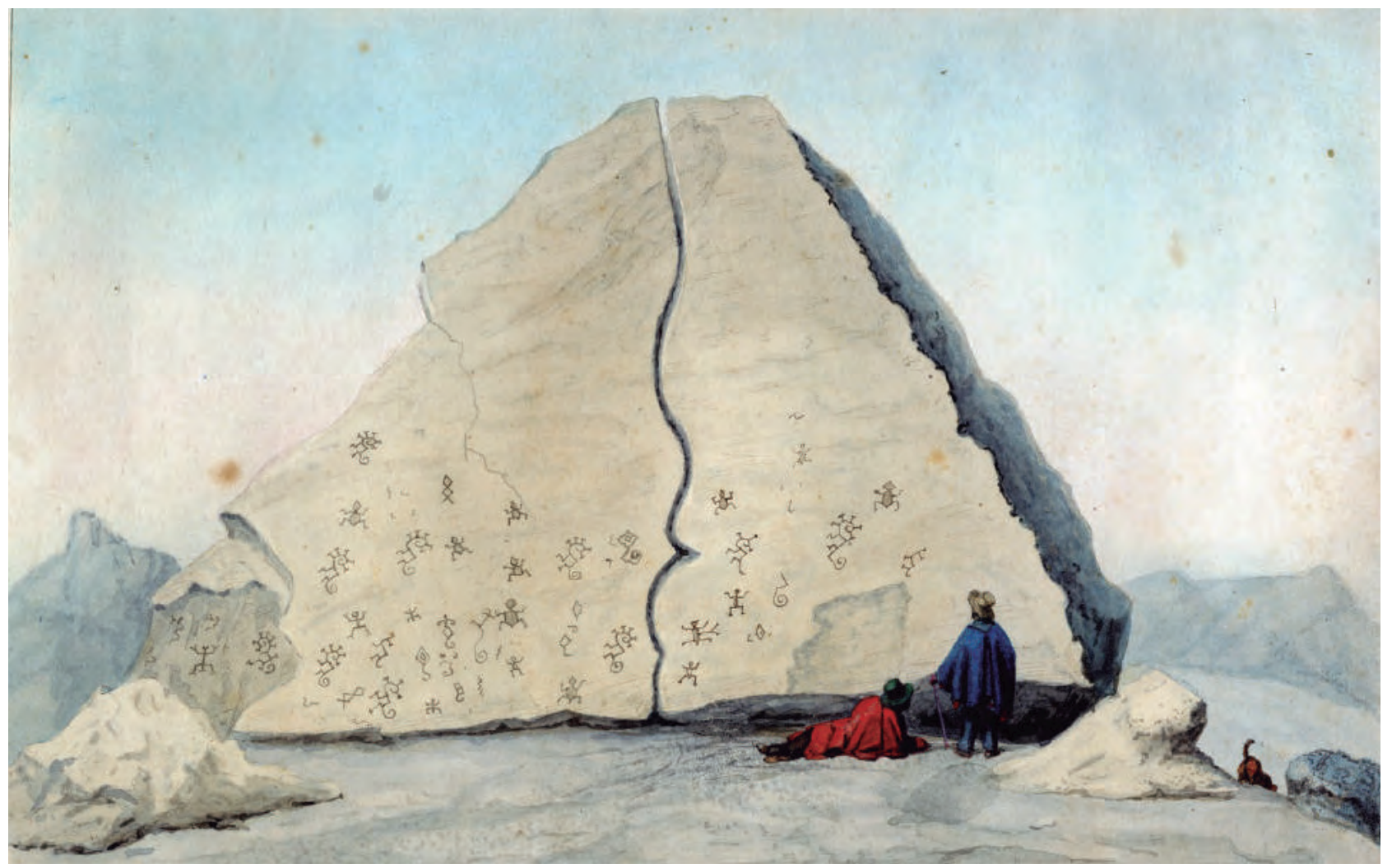

Piedra grabada de Gámeza, Provincia de Tundama. Carmelo Fernández. (1850-1852). Acuarela. Fuente: Obtenida en octubre 15 de 2018, de https://www.wdl.org/es/item/9032/\#q=chibchas\&qla=es 
Ofrendatario representante de poder. Región arqueológica muisca, altiplano cundiboyacense. 1000 d.C. (Cronología relativa) Cerámica. Colección Instituto Colombiano de Antropología e Historia, pieza exhibida en el Museo Nacional de Colombia. Cód. ICAHN 38-I189 / 38-|-184. Fotografía: Diego Carrizosa.

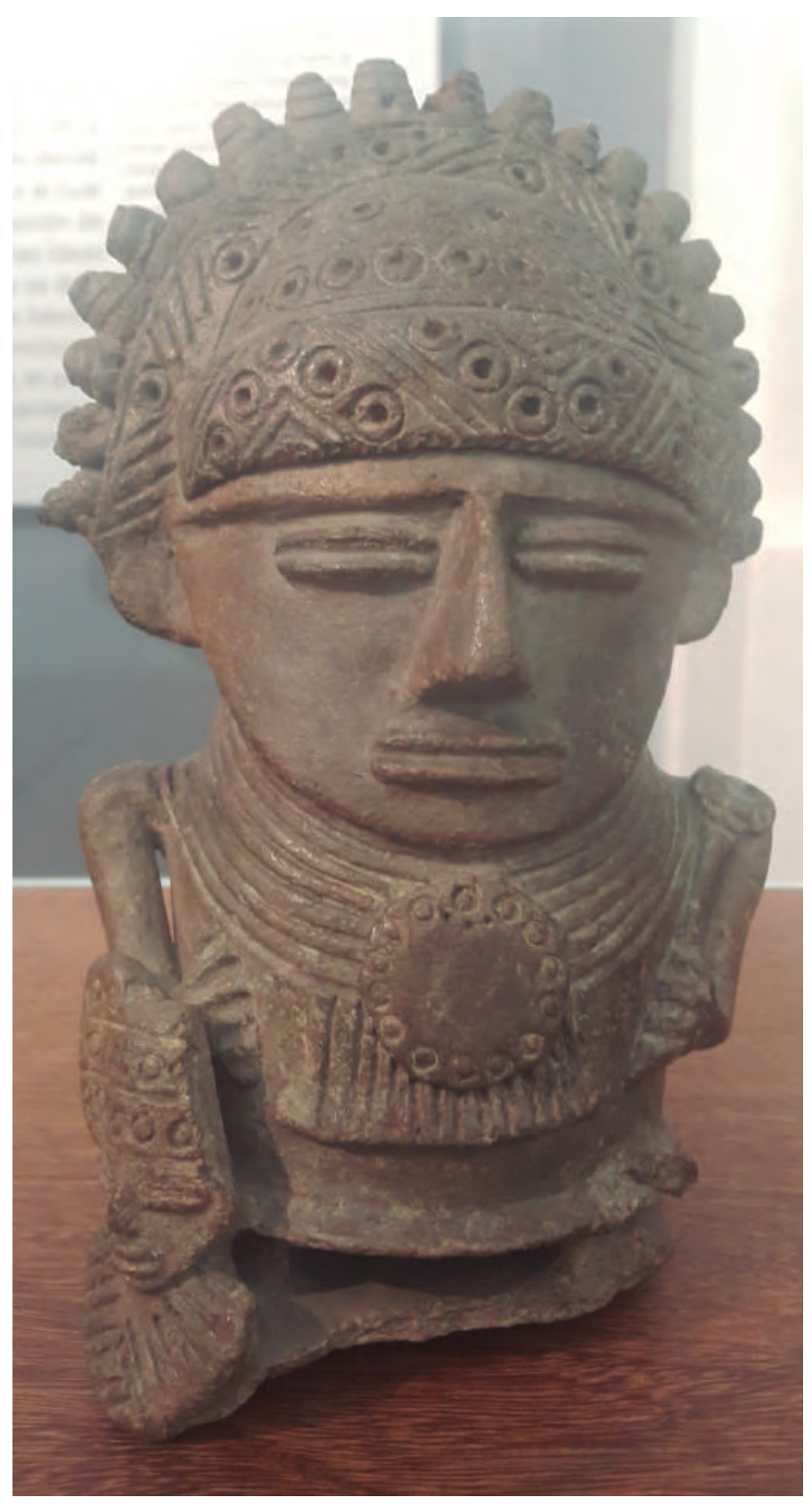




\section{Representación cosmogónica chibcha}

\section{El zipa}

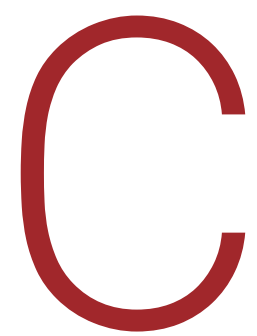

omo se ha expresado, Acuña investigó el arte precolombino, divulgó los resultados de sus investigaciones por medio de publicaciones e interpretó y representó plásticamente los trabajos que eran de su interés, entre ellos, las figuras que hacian parte de la organización política de la sociedad chibcha. Tal es el caso de la imagen del zipa (figura 15), dibujada por Acuña a partir de la observación de una pieza de orfebrería chibcha (figura 16), cuya interpretación, según la visión creativa de Acuña, se puede observar en la figura 17.

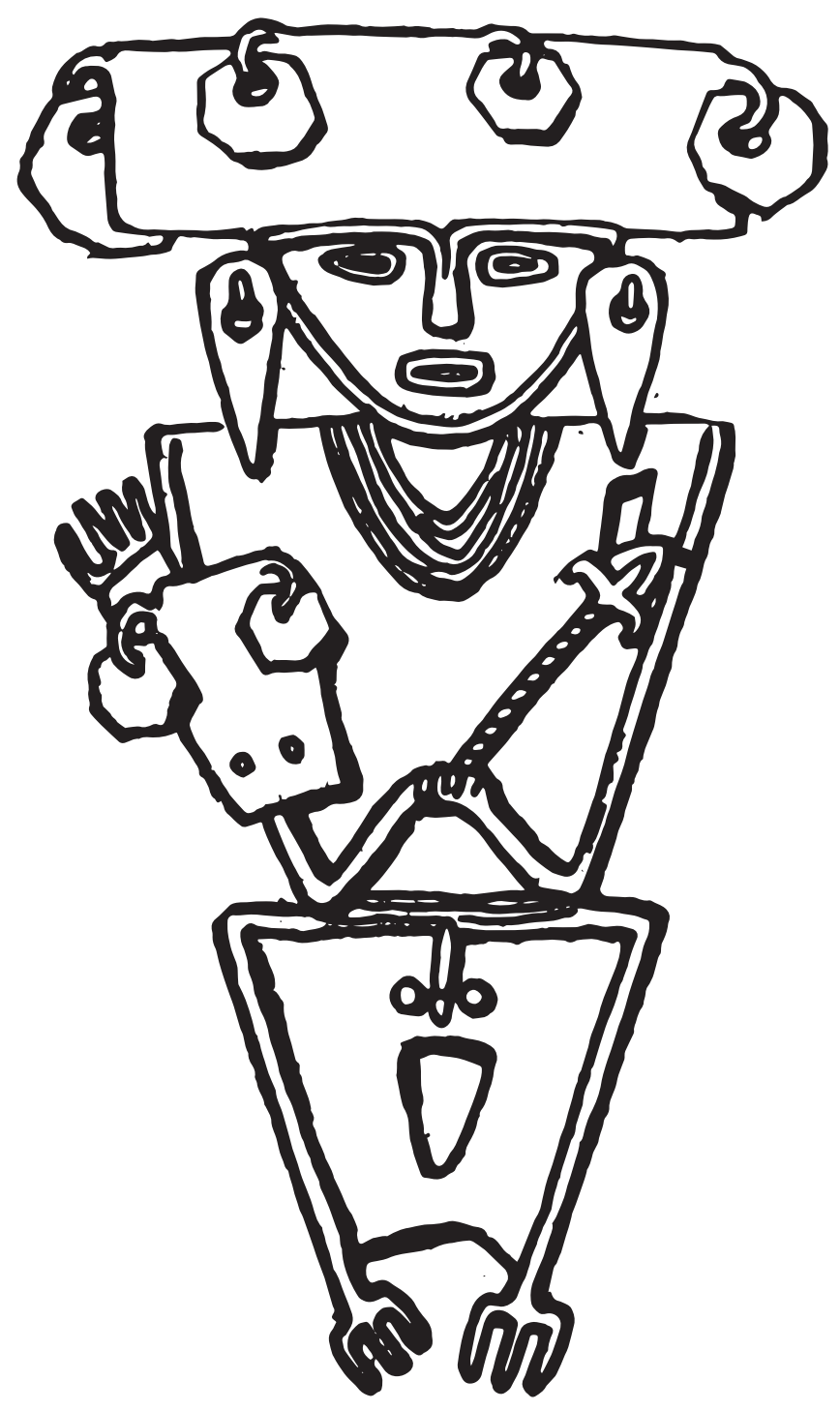

Figura 15.

Dibujo de la imagen de un zipa, realizado a partir de la orfebrería chibcha. Fuente: Acuña (1935). 
Figura 16.

Representación de una figura votiva.

Orfebrería muisca-guane. Banco de la República - Colección del Museo del Oro-, titular de los derechos de autor. Fotografía: Diego Carrizosa. 


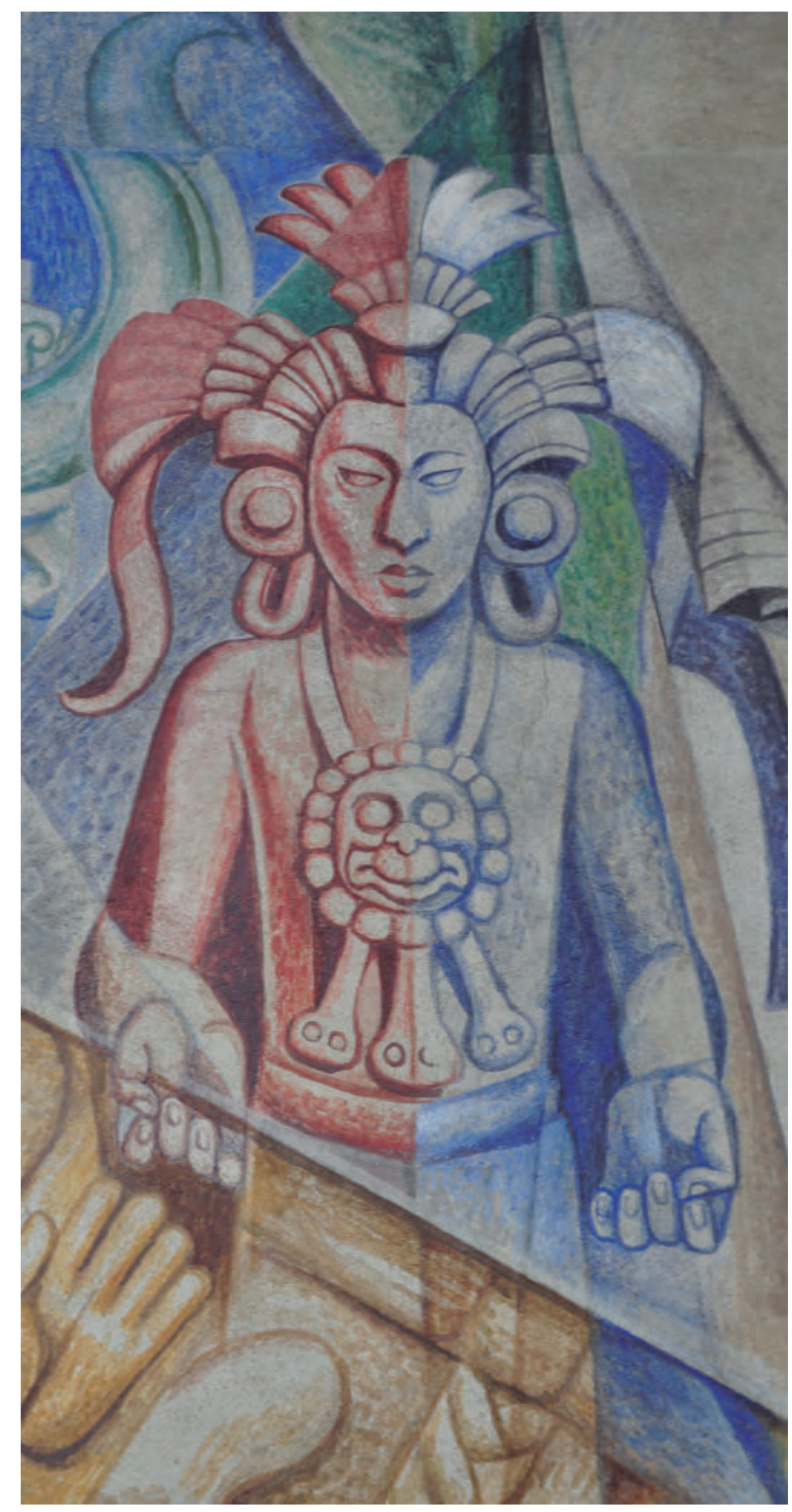

\section{Figura 17.}

Un zipa. Fragmento del mural Colón descubre el Nuevo Mundo (Luis Alberto Acuña 1967).

Localización: Centro Médico Almirante Colón, Bogotá. Fotografía: Diego Carrizosa.

Sobre el referente de la imagen del zipa elaborada en oro (figura 16), Acuña anotó:

Pues para la representación de divinidades y caciques se procedía de manera muy esquemática, trazando con hilo de oro, sobre plancha recortada del mismo metal, formas muy estilizadas y lacónicas pero suficientes para una impresión de lo que el artífice quiso representar. En la confección de los pectorales, las ajorcas, pulsos, arracadas, y otras joyas, la lámina sometida a mínima delgadez era repujada con puntos sucesivos, rayados paralelos, animales esquematizados y otros motivos, todos muy simples, los más simples de todo su repertorio ornamental. $(1935,57)$

En la figura 17, se puede observar un fragmento del mural Colón descubre el Nuevo Mundo (1967), que representa a un zipa y donde se pueden rastrear 
los rasgos de un rostro ovoide, pómulos salientes, boca relevante, ojos oblicuos y tronco ancho. El dibujo es preciso y su paleta comprende colores fríos; la figura contiene los elementos de mando, como es el caso del bastón, de los collares ceremoniales, así como las plumas de ave, que eran utilizadas en la forma de ofrenda.

\section{El jeque}

Los sacerdotes de los chibchas eran llamados jeques y no se presentaba entre ellos el caso de diferenciaciones de tipo jerárquico. Y según Uricoechea (1984),

[...] eran los depositarios de todo el saber abstracto de los chibchas, el cual se extinguió con ellos inmediatamente después de la Conquista, pues esta clase fue necesariamente la más perseguida por falta de hombres bastante instruidos entre los españoles, para hacer la distinción entre lo que tocaba a la idolatría que convenía extirpar, y lo que decía en relación con materias útiles al conocimiento de su historia y las antigüedades. (52)

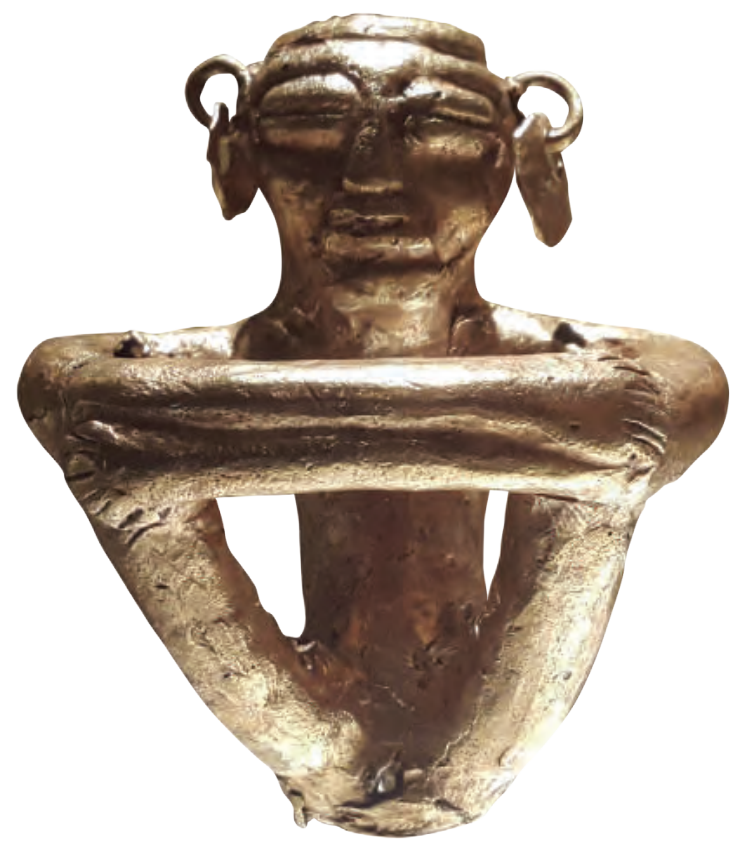

Figura 18.

Representación del jeque en posición de meditación. Orfebrería muisca-guane. Banco de la República - Colección Museo del Oro-, titular de los derechos de autor. Fotografía: Diego

Carrizosa. 
Figura 19.

Representación del Jeque en posición de meditación. Cerámica chibcha. Colección ICANH. Fotografía: Diego Carrizosa.
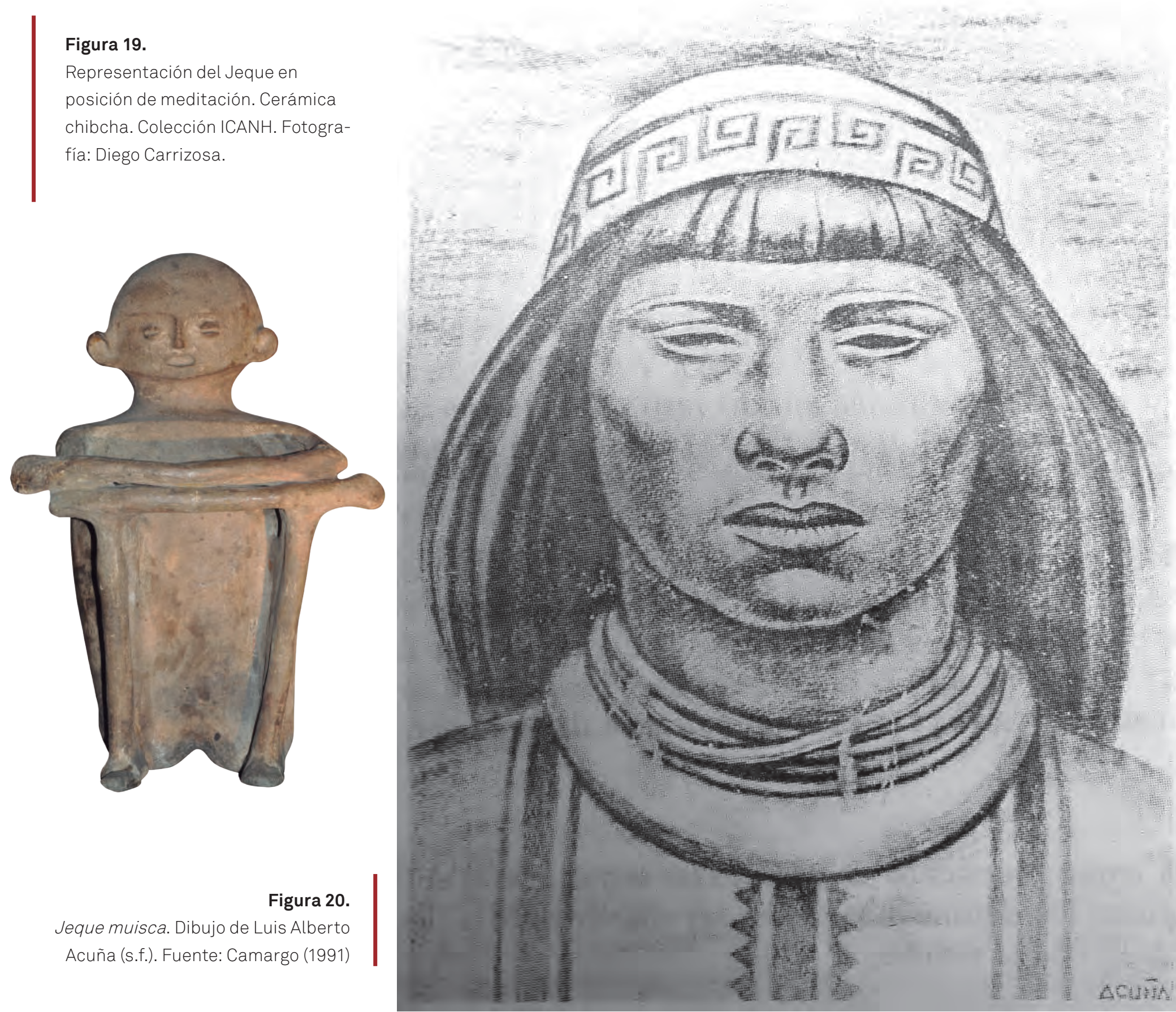

Jeque muisca. Dibujo de Luis Alberto Acuña (s.f.). Fuente: Camargo (1991) 


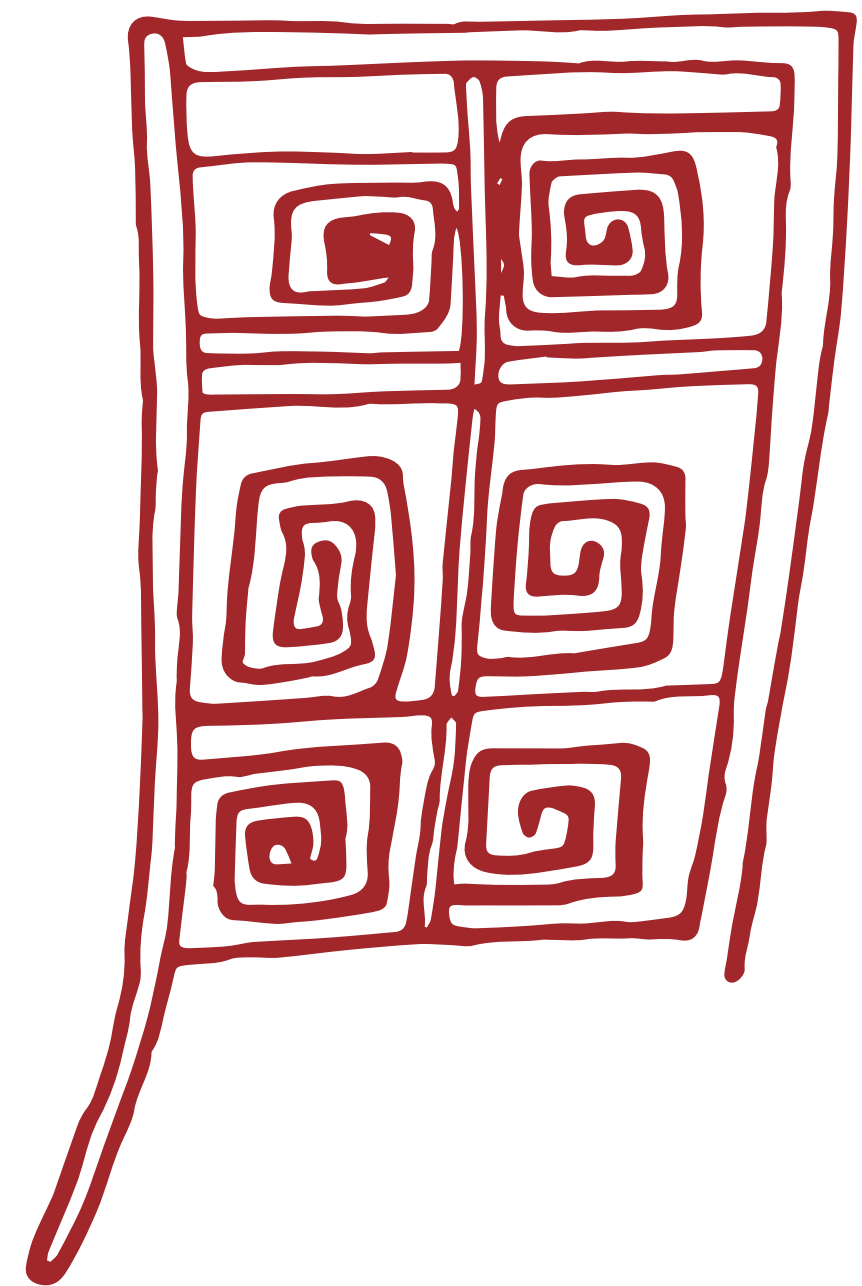

Figura 21.

Dibujo de un fragmento de arte rupestre.

(Plancha XVII) Pandi, Cundinamarca.

Fuente: Triana (1924).
En las tres figuras que se aprecian en la página anterior, aparecen tres versiones diferentes de esta autoridad religiosa chibcha; en la figura 21, se encuentra un dibujo de un fragmento de arte rupestre. En las figuras 18 y $\mathbf{1 9}$, se puede observar la representación de un jeque chibcha en estado de trance. La figura 18 que se encuentra en la colección del Museo del Oro en Bogotá está acompañada por el siguiente texto que pertenece a su ficha museográfica:

“Los pensadores prehispánicos [...] desarrollaron técnicas corporales para mediar y comunicarse con el mundo sobrenatural. Al sentarse en determinadas posturas adquirían estados de intensa concentración y evocaban conceptos cosmológicos".

Tal es el caso de los brazos entrecruzados y posiblemente la posición de las piernas de las figuras del jeque que se observan en las figuras $\mathbf{1 8}$ y 19. Además, para lograr el estado de intensa concentración, el jeque recurría a la ingestión del yopo, un poderoso alucinógeno que le permitía entrar en estados alterados de conciencia, con el fin de consumar sus obligaciones de adivinación, curación y comunicación con los seres que hacian parte de su cosmogonía. Acuña (1935) habló sobre la representación en cerámica de un jeque y connotó el arte 
prehispánico como estancado y pleno de exotismo, detenido porque los chibchas no llegaron a la Edad de Bronce y, por ende, no tuvieron la posibilidad de diseñar y utilizar en su arte herramientas fabricadas en metal, situación que les otorgaría un mejor dominio sobre su trabajo. Lo exótico responde a que la cosmogonía de esta sociedad era el resultado de una extraña mezcla de lo supremo con lo extravagante. Respecto de la función religiosa de los jeques, Acuña (1935) sostuvo que esos sacerdotes educaban al zipa sobre aspectos como ser un buen gobernante, acerca de cómo leer los astros, sobre las formas en que se debía adorar a sus dioses y sobre su tradición cultural ancestral. El dibujo del jeque realizado por Acuña (figura 20) mantiene los rasgos fenotípicos del chibcha, resaltando los ojos pequeños, enmarcados por los párpados alargados muy semejantes a los que se observan en las piezas de cerámica y oro. Sin embargo, la cabeza, la boca y la nariz del jeque difieren en su forma en las

figuras $\mathbf{1 8}, \mathbf{1 9}$ y $\mathbf{2 0}$, razón que obedece a la posición de autor que se reserva cada uno de los creadores de las obras. En este sentido, el filósofo Francisco Posada Díaz (2014) se refirió a los trabajos realizados en cerámica por parte de los chibchas en los que resalta la manera estilizada en que representaban las figuras de caciques y dignidades, mediante la cual buscaban efectos determinantes (figura 19).
Como rasgo sobresaliente, puede señalarse el de su notable valor espiritual, que se marca en el hecho de que son obras donde, según Acuña (1952a), hay "serenidad y placidez interior". Se estaba operando, pues, el proceso de divinización del hombre (Posada 2014, 665).

Sobre la balaca tejida que lleva el jeque en su frente, es importante mencionar que Acuña (1942) sostuvo que en la comunidad chibcha todos tejían, y que el arte de hilar era ejercido tanto por las mujeres sin rango como de casta, y que según Triana (1924) este tipo de producto gozaba de gran importancia dentro de su industria. Acerca del diseño que posee la balaca (figura 21), se cree que la fuente que posiblemente pudo haber utilizado Acuña para basar su dibujo fue la representación rupestre reseñada por Triana (1924), hallazgo documentado por los miembros de la Comisión Corográfica en 1852 en Pandi (Cundinamarca).

Sobre las críticas que se realizaron sobre la obra de Acuña, según Friede (1946), se puede mencionar que hubo contradicciones fuertes, como es el caso del texto escrito por un crítico del periódico El Excélsior de México sobre la exposición realizada por Acuña el 16 agosto de 1940 en el salón de la Galería de la Universidad Autónoma de México: 
Acuña es un buen pintor a pesar de la falta de emoción directa, de matrices de movimiento, de proceso sentimental que hay en cada uno de sus cuadros. Lo es, porque dibuja con pureza y precisión raras [...] Los cuadros "académicos" de los dioses chibchas, dice el mismo crítico, son exponentes de una insinceridad casi total y de una autolimitación estética, que se traduce lo mismo en la composición monótona de las figuras, que en el egoísmo y sentimental uso de los colores, de tonos exorbitantes. (citado por Friede 1946, 48)

Se estima, sin embargo, en contra de la opinión del crítico mexicano, que la pintura de Acuña es sincera, por cuanto es considerada como el resultado de la interpretación de sus investigaciones acerca de la cosmogonía chibcha y su sueño creador. Su poética obedece a un concepto de figuras de gran volumen al cual ha llegado el artista después de una búsqueda sobre un lenguaje plástico propio mediante el que representa las diferentes formas de su arte. Su aparente composición monótona es posible que responda a una estructura concebida a partir de la ley de tercios (organización de objetos dentro de una imagen), herencia de sus enseñanzas de tipo académico recibidas en las academias europeas; sus colores con "tonos exor- bitantes" son los colores del trópico, que provienen de la misma luz que iluminó a las sociedades prehispánicas y que se reflejó de igual manera sobre la tierra americana de Acuña.

Sobre su posición como artista, Acuña sustentó el siguiente pensamiento veintisiete años después de la aparición del artículo del mexicano:

De otra parte y como quiera que el arte es un ejercicio de la libertad, justo es concebir al artista como un ser autónomo cuyo albedrío no admite cortapisas; hallándose expedito para escoger su camino, el artista puede inclusive, siguiendo las leyes ancestrales, enderezar sus pasos por la senda de la tradición [...] ¿Es que constituye acto de autonomía el aceptar las modernas, las más avanzadas y ultraístas expresiones que nos llegan de fuera, incondicionalmente y sin someterlas a la rigurosa cuarentena de la adecuación al medio y del condicionamiento las propias y muy personales convicciones?

La rebeldía de la joven generación bachué del año 30 radicó precisamente en no aceptar de las corrientes entonces en boga nada que no fuese consecuente con las circunstancias históricas y ambientales del momento en que actuó. Pero la rebeldía de las generaciones 
posteriores ¿en qué se origina y fundamenta y contra qué se dirige? Se dirá que contra todo principio establecido y contra toda formalidad académica, lo cual es decir gran cosa, y no decir nada; pues el academicismo posee en sus fundamentos sólidos, invulnerables conocimientos de oficio y principios técnicos tradicionales de evidente sabiduría, para lograr, lo cual es indispensable, el sometimiento a largas y dolorosas disciplinas. (Acuña 1965-1986, 48-49)

Se desea terminar este capítulo con una frase de Juan Friede, quien escribió, en 1946, desde la tierra de la antigua cultura de San Agustín, lo siguiente: "El papel que juega la obra de Luis Alberto Acuña en este renacimiento cultural de Colombia, sólo lo apreciarán las generaciones futuras" (52).
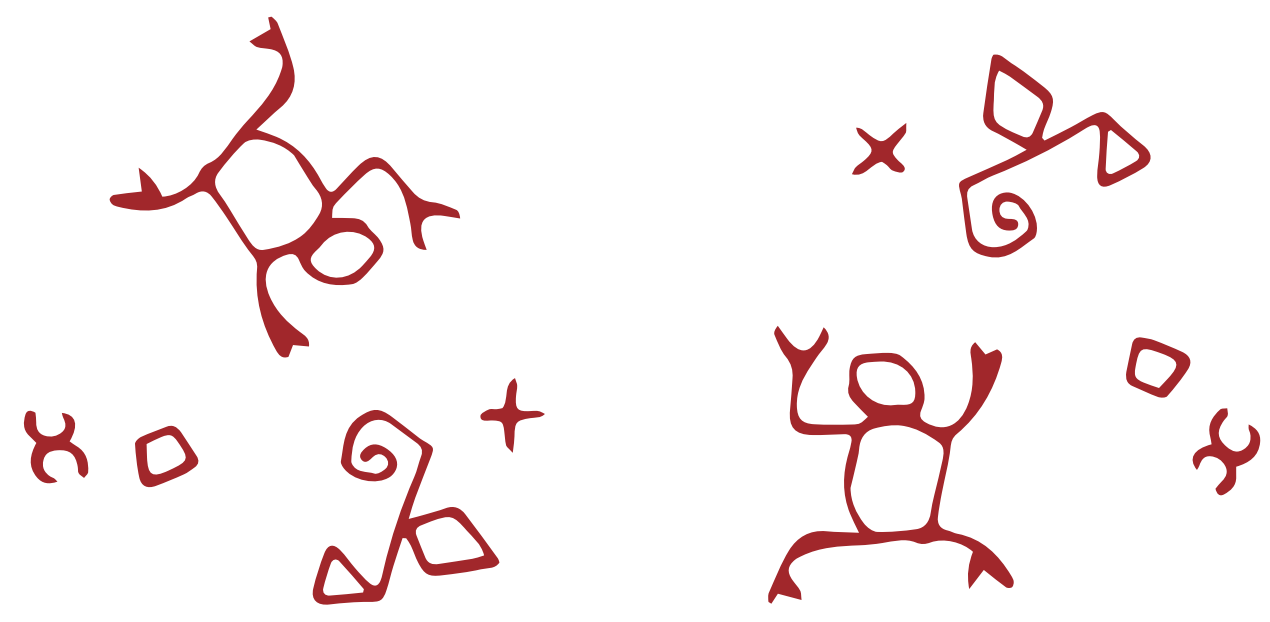


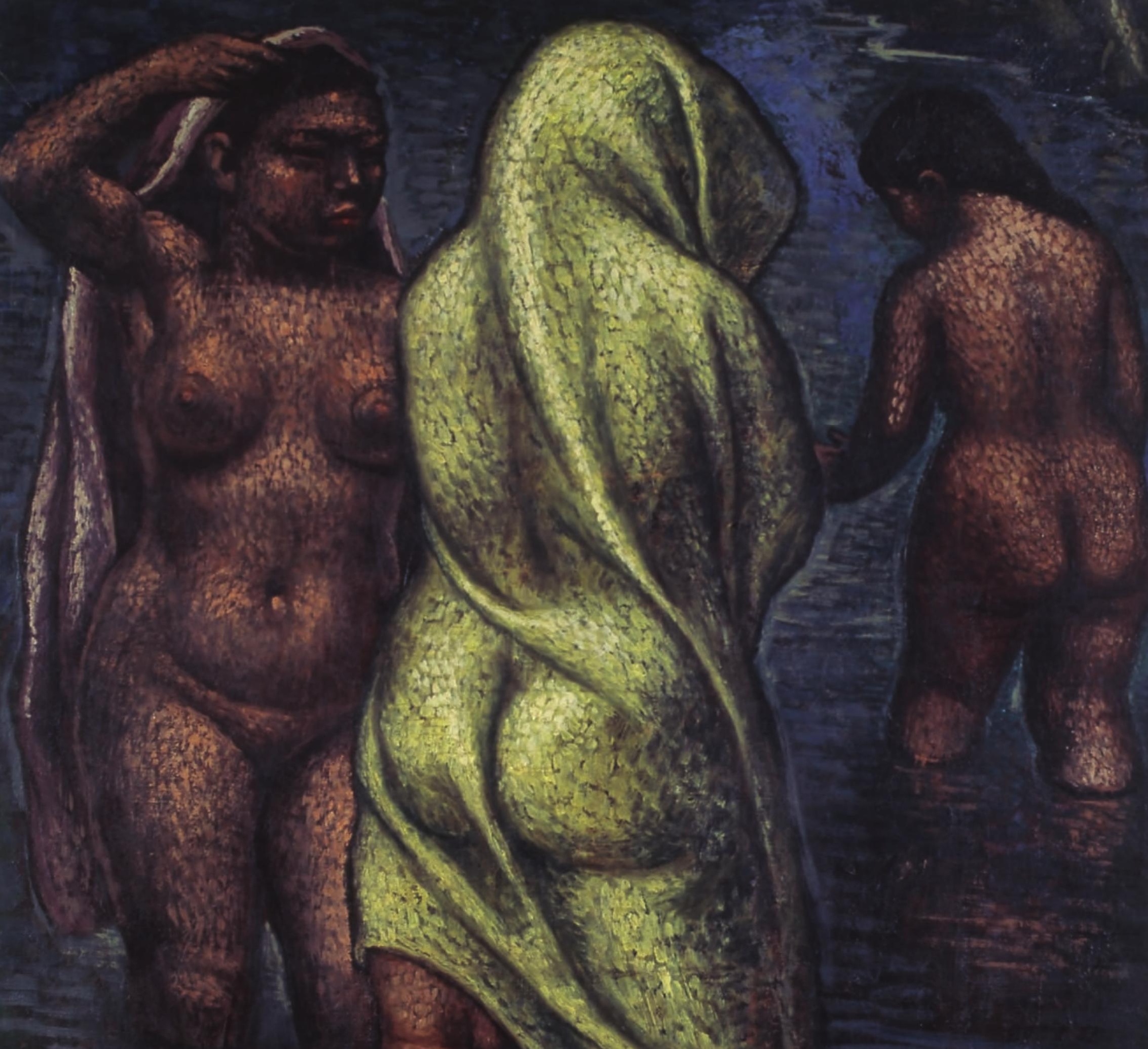

